\title{
Ore Mineralogical and Geochemical Studies on El-Daghbag-I Gold Deposit, Central Eastern Desert, Egypt
}

\author{
Khairiya M. Fawzy \\ Geology Department, Faculty of Science, Aswan University, Aswan, Egypt \\ Email:khairiyafawzy@yahoo.com
}

How to cite this paper: Fawzy, Kh.M. (2017) Ore Mineralogical and Geochemical Studies on El-Daghbag-I Gold Deposit, Central Eastern Desert, Egypt. Open Journal of Geology, 7, 395-419.

https://doi.org/10.4236/ojg.2017.73027

Received: February 3, 2017

Accepted: March 27, 2017

Published: March 30, 2017

Copyright $\odot 2017$ by author and Scientific Research Publishing Inc. This work is licensed under the Creative Commons Attribution International License (CC BY 4.0).

http://creativecommons.org/licenses/by/4.0/ (c) (i) Open Access

\begin{abstract}
El-Daghbag-I gold mineralization is a part of El-Daghbag gold deposit, Central Eastern Desert, Egypt. It is represented by several NW-trending quartz veins cutting across highly sheared granodiorite rocks along NW-trending shear zone. The recorded ore mineral assemblage is magnetite, ilmenite, native gold, pyrite, chalcopyrite, sphalerite and galena. Bornite, covellite and goethite are the secondary ore minerals. Statistical parameters, Clark of Concentration, linear productivity, contrast coefficient, zonality index and zoning coefficient were calculated to investigate the geochemical association and whether there are factors controlling distribution of its members. The geochemical primary distribution patterns of gold and the elements properly forming the mineralization revealed that the gold associated elements are $(\mathrm{Cu}$, $\mathrm{As}, \mathrm{Zn}, \mathrm{Ni}, \mathrm{Co}, \mathrm{Ag}$ and $\mathrm{Pb}$ ). These elements occur as proper ore sulfide-minerals. The recorded lateral zoning sequence of deposition along the NW-SE extension of the main quartz vein is (Ag-Co-Ni-Cr-Cu-As- $\mathrm{Zn}-\mathrm{Pb})$. The lateral zoning sequence along the SW-NE trend crossing the quartz vein exhibits variable depositional sequence is (Ag-Co-Cr-Ni-Cu-As-Pb-Zn). With regard to position of the ore metals in the general sequence of zoning, the gold potential of the central and southeastern parts, due to its probable accumulation at deeper levels of the mineralization, are expected to be promising. Drilling is recommended for studying the vertical zoning of these elements to reveal the site of gold accumulation.
\end{abstract}

\section{Keywords}

Ore Mineralogy, Geochemistry, Gold Deposit, Wadi El-Daghbag, Eastern Desert, Egypt 


\section{Introduction}

The Egyptian Eastern Desert is one of the largest gold provinces in the world where more than 96 gold deposits and occurrences are recorded. Gold mineralization in the Eastern Desert of Egypt is almost confined to the gold-bearing quartz veins and the associated alteration zones within ophiolitic and island-arc igneous and metamorphic rocks of the Arabian Nubian Shield ([1]-[6]). Numerous geological and geochemical data on the gold mineralization in the Eastern Desert were obtained (e.g. [7]-[20]).

Wadi El-Daghbag area lies in the central part of the Nubian Shield, Eastern Desert of Egypt between latitudes $25^{\circ} 20^{\prime}$ and $25^{\circ} 26^{\prime} \mathrm{N}$, and longitudes $33^{\circ} 47^{\prime}$ and $33^{\circ} 54^{\prime} \mathrm{E}$ (Figure 1). El-Daghbag gold mine witnessed extensive ancient mining of gold-bearing quartz veins. Ptolemaic Period beneficiation and extraction of gold are supported by the abundant tools in Wadi El-Daghbag [21].

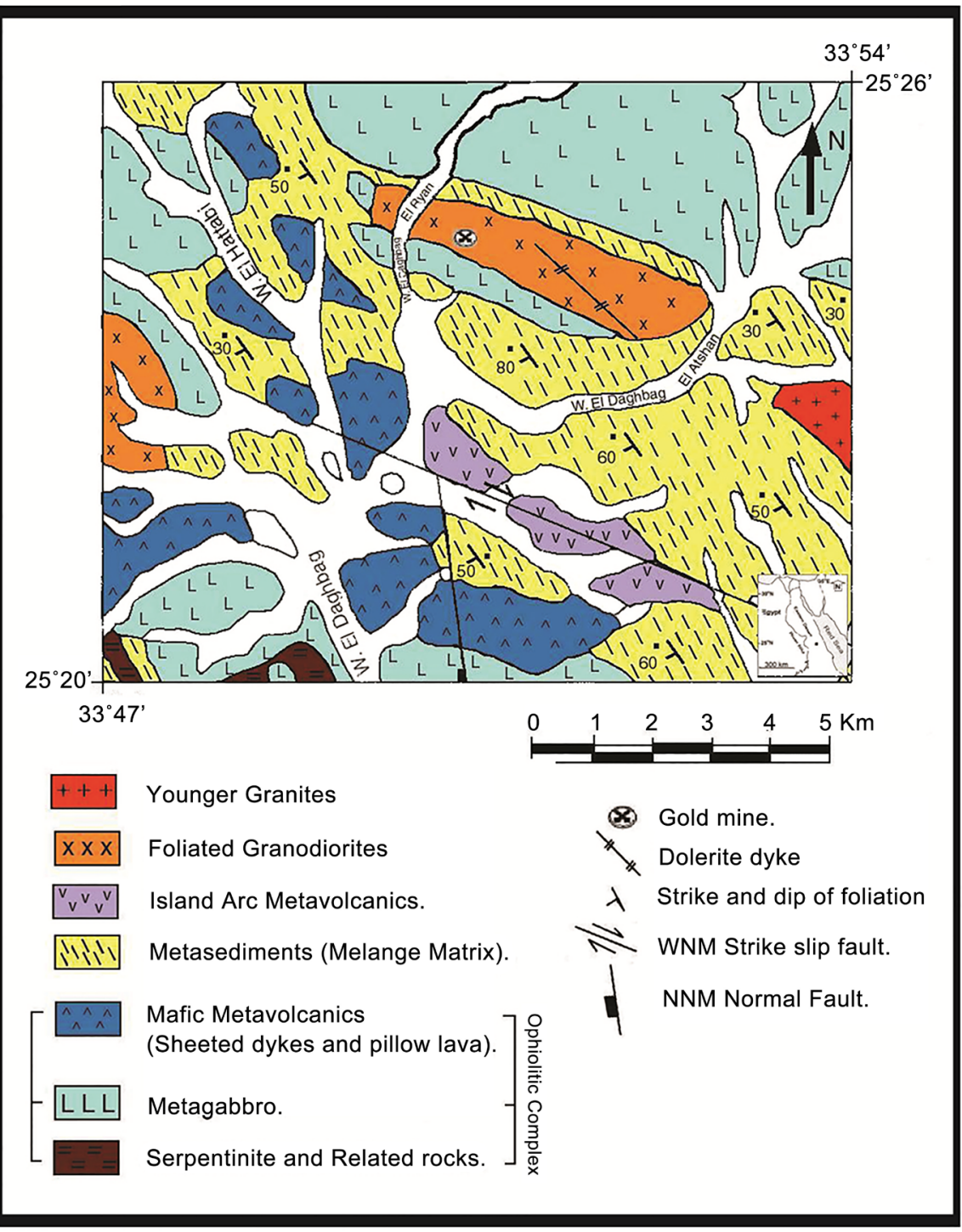

Figure 1. Geologic map of El-Daghbag gold mine area, central Eastern Desert of Egypt (after [24]). 
A total of 39 quartz veins traverse Wadi El-Daghbag area in several sites [22]. The quartz veins are milky, milky brown or smoky in color running in different directions and dipping at $25^{\circ}$ to $90^{\circ}$. Their extension reaches up to $400 \mathrm{~m}$ and thickness varies from 0.2 to $7 \mathrm{~m}$. Gold content in the veins are recorded up to $15.5 \mathrm{~g} /$ ton by [22], up to $39 \mathrm{~g} / \mathrm{t}$ by [23] and ranging from 0.3 to $6 \mathrm{~g} / \mathrm{t}$ by [24]. The main veins are concentrated around Bir El-Daghbag. Unambiguous traces from ancient extraction are however made out in four separate quartz vein systems namely El-Daghbag-I, II, III and VI [23]. The El-Daghbag-I gold mine is located in east of Wadi El-Daghbagh El Rayan (a NE-SW trending tributary of Wadi ElDaghbag) at the intersection of Latitude $25^{\circ} 24^{\prime} 11^{\prime \prime} \mathrm{N}$ and Longitude $33^{\circ} 49^{\prime} 13^{\prime \prime} \mathrm{E}$ (Figure 1). It is relatively narrow but very deep to be judged by the large waste dump located just outside.

The present work addresses the ore mineralogy and paragenetic relations of the El-Daghbag-I gold mineralization, and discusses the geochemical distribution of gold and associated elements in the mineralized zone to reveal the site of gold accumulation. This study is based on detailed mineralogical and lithogeochemical studies of the quartz vein, the associated hydrothermal alteration zone and the host rock.

\section{Geologic Setting}

El-Daghbag gold mine area is covered by a Precambrian ophiolite sequence intermixed with a mélange matrix (metasediments), island arc metavolcanics, older and younger granites, dykes and quartz veins [24].

A Precambrian complete ophiolite sequence was recognized and described by [25] in Wadi El-Daghbag area and in vicinity. This ophiolite sequence consists of serpentinites and related rocks, metagabbro, mafic metavolcanics (sheeted dykes and pillow lava) and pelagic sediments (chert). The island arc metavolcanics are formed of repeated alternating and intercalated successions of basaltic andesite and andesite flows together with layered dacite and rhyodacite flows. The older granites are represented by quartz-diorites and granodiorites. The younger granites are represented by monzogranites and syenogranites [26]. The area suffered shearing represented by a chief shear zone trending NW-SE.

El-Daghbag-I gold mineralization is represented by several NW-trending quartz veins along NW-trending shear zone cutting across highly sheared granodioritic rocks. Numerous open pits and mining work are spread over the quartz veins. The main mineralized vein is highly compact massive milky quartz trending $\left(\mathrm{N} 60^{\circ} \mathrm{W}\right)$, steeply dipping to the SW. It is about 110 meters length and up to $120 \mathrm{~cm}$ width. The vein is conformable with the foliation of the host granodioritic rocks and exhibiting noticeable pinch and swell structure. The main mineralized vein has been stopped out through several trenches (Figure 2(a)) and steeply inclined shafts. Old mining took place only within the hanging wall of the quartz vein and the associated alteration zones next to them while its central part remained unminable (Figure $2(\mathrm{~b})$ ). The vein is affected by NE-SW faults (Figure 2(c)) and furcating to form dense network of quartz veinlets 
(Figure 2(d)). The furcating quartz veins are commonly separated by strongly altered rocks. The alteration zones around the furcated quartz veins range from few centimeters to three meters thick related to the variable width of the quartz veins.

\section{Methodology}

Forty two samples were collected from the main mineralized quartz vein, associated alteration zones and host rocks at El-Daghbag-I gold mine. The samples were taken along three profiles traversing the surface level to cover the main mineralized quartz vein from its NW-beginning to the SE-end (Figure 3). $\mathrm{Nu}$ merous samples were also collected from the dump of the old workings and the mouth of shafts. A total of 25 polished surfaces of representative samples were prepared and subjected to ore microscopic study, scanning electron microscope (SEM) and the energy dispersive X-ray spectrometer (EDX) studies. Twenty five representative samples were analysed for $\mathrm{Ag}, \mathrm{As}, \mathrm{Co}, \mathrm{Cr}, \mathrm{Cu}, \mathrm{Ni}, \mathrm{Pb}$ and $\mathrm{Zn}$ using the XRF technique. Both laboratory works were undertaken in the laborato-

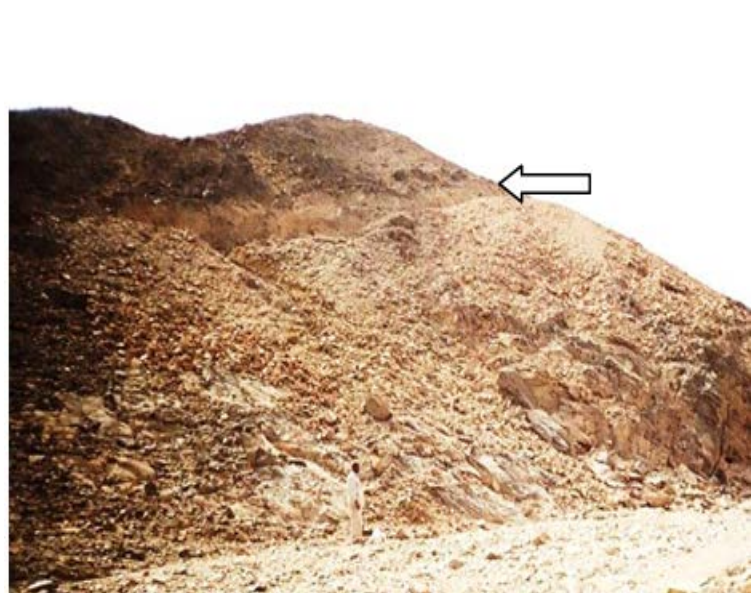

(a)

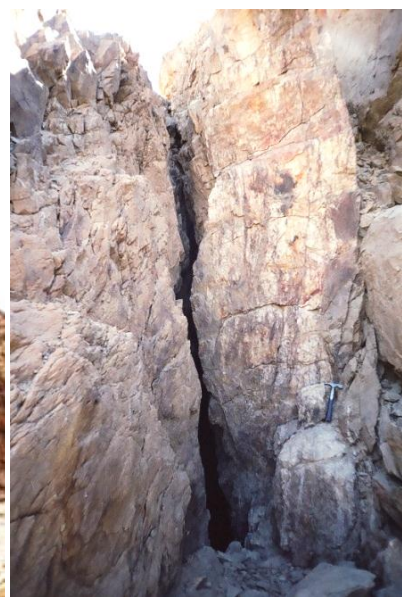

(b)

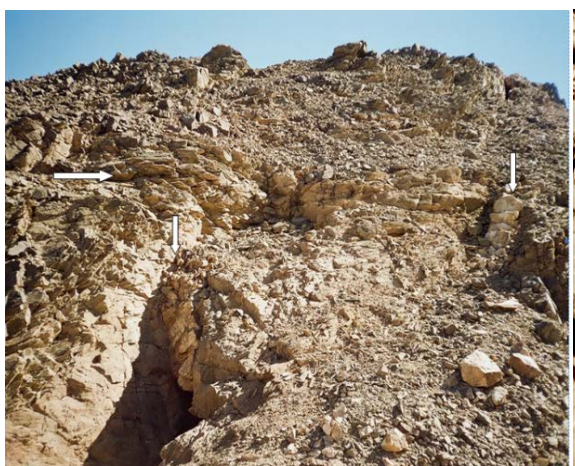

(c)

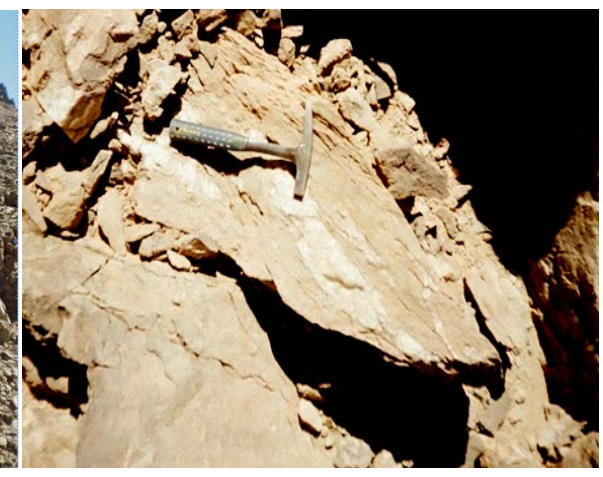

(d)

Figure 2. Photographs showing the El-Daghbag-I gold mineralization. (a) Granodiorite traversed by trench along the main vein; (b) The central quartz vein left unminable; (c) The displacement of the vein along a fault plane; (d) Quartz veinlets cutting the granodiorite. 


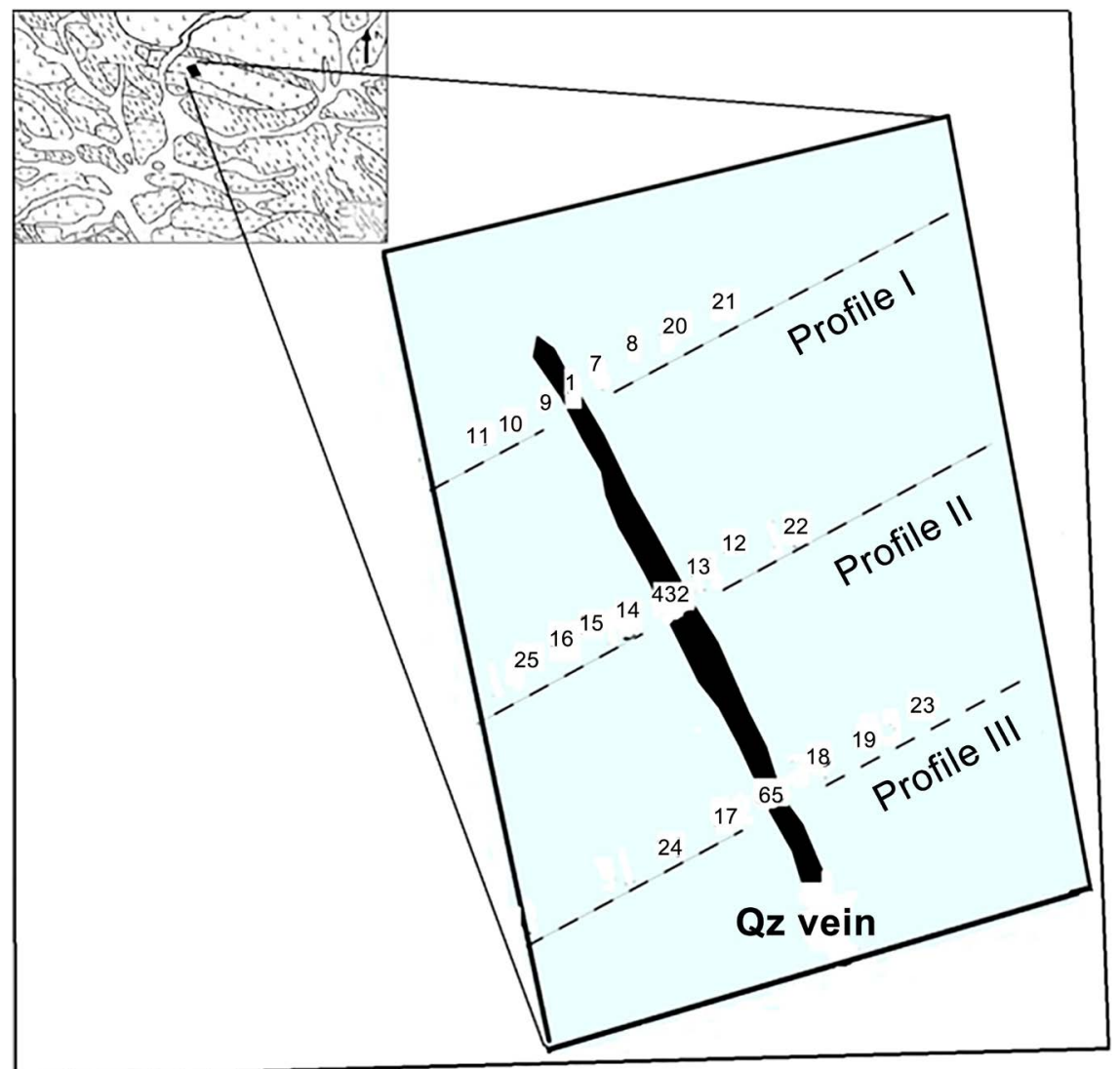

Figure 3. Location of samples along the NW, central and SE profiles cutting across the main mineralized vein of El-Daghbag-I gold mine.

ries of Nuclear Materials Authority, Cairo. Moreover, gold analysis was conducted using the fire assay method in the Central Laboratories of the Geological Survey of Egypt.

The calculated statistical parameters (arithmetic mean, X; Standard Deviation, S.D.; Variation Coefficient, V.C. and correlation coefficient, r) and the geochemical parameters (Clark of Concentration, CC and zoning coefficient, $V$ ) were used to delineate the primary concentration phase to reveal the characteristics of lithochemical distribution patterns of the ore metals, probable zonation of metals, site of gold accumulation in relation to level of the erosional section following [27] [28] [29] [30] [31].

In geochemical exploration, the most reliable criteria is the linear productivity $(M$, Equation (1)) is calculated as the amount of chemical element in excess of the background value, along particular cross section to represent the geochemical anomaly using the following equation:

$$
M=\Delta \mathrm{X}\left(\sum C i-n C_{b}\right)
$$

where $\Delta \mathrm{X}$ is the sampling interval along the profile, $n$ is number of samples on the profile, $C i$ is the element content in the analyzed samples and $C_{b}$ is the geochemical background of element.

The contrast coefficient is laterally determined by using formula (2). 
Contrast Coefficient $=$ Content of the element in the northern start point /Content of the element in the southern end point

The elements are to be arranged in decreasing order of their contrast coefficient values. The resulting sequence will illustrate the geochemical zonation of the elements.

Zonality index of an indicator (pathfinder) element is defined as the ratio of linear productivity of a given element in the studied mineralization to the sum of linear productivities of all pathfinder elements in each lateral profile expressed by formula (3).

$$
\text { Zonality index }=M /\left(\sum M i, n\right)
$$

The zoning coefficient $(v)$ manifests the difference in the concentration $\left(C_{i}\right)$ or productivity $\left(M_{i}\right)$ of the associated trace elements to those of the main ore element $\left(C_{1}\right.$ or $\left.M_{1}\right)$ at different distances from the center or periphery of ore body. It was calculated by using the following Equation:

$$
v=C_{i} / C_{1} \text { or } M_{i} / M_{1}
$$

where $v=$ zoning coefficient, $M_{i}=$ productivity for the associated elements, $M_{l}=$ productivity for the main element. In the present study, zoning coefficient values were obtained along lateral profiles, by calculating the ratio values between concentration of most inert ore element (lead) and each of associated elements.

\section{Ore Mineralogy}

The recorded primary ore minerals forming the assemblage of El-Daghbag-I gold mineralization is magnetite, ilmenite, native gold, pyrite, chalcopyrite, sphalerite and galena. Bornite, covellite and goethite are the secondary ore minerals. Native gold occurs as small irregular single fine grains, specks and blebs in the quartz veins, alteration zones and host rocks. The gold grains are distributed and encountered within iron oxide groundmass (Figure 4(a)) or enclosed in altered sulfide minerals (Figure 4(b)). Gold grains occasionally occur as oriented fine disseminations filling the microfractures and fissures (Figure 4(c), Figure $4(d))$. The presence of native gold is noticed, to be enriched in the periphery of the studied quartz vein at the contact with the alteration zones, more than in the core.

In the samples of the alteration zones and the granodiorite host rock gold occurs as fine individual or aggregated crystals (Figure $4(\mathrm{e})$ ) and as very fine specks filling microfractures and fissures (Figure 4(f)). The (SEM) examination and EDX of polished surfaces of the alteration zone (Figure 5(a)) revealed presence of admixture or alloy of silver and gold occurring as electrum ( $\mathrm{Au}, \mathrm{Ag}$ ). The study of polished surfaces of the quartz vein, alteration zone and host rock samples recorded presence of pyrite as fine-grained aggregates moderately to highly altered to goethite. Fine remnant relics of pyrite still exist within the goethite crystals (Figure 5(b)).

Fine-grained anhedral chalcopyrite crystals are recorded scattered and filling both the cavities and fissures in the quartz vein, alteration zone and host rock 

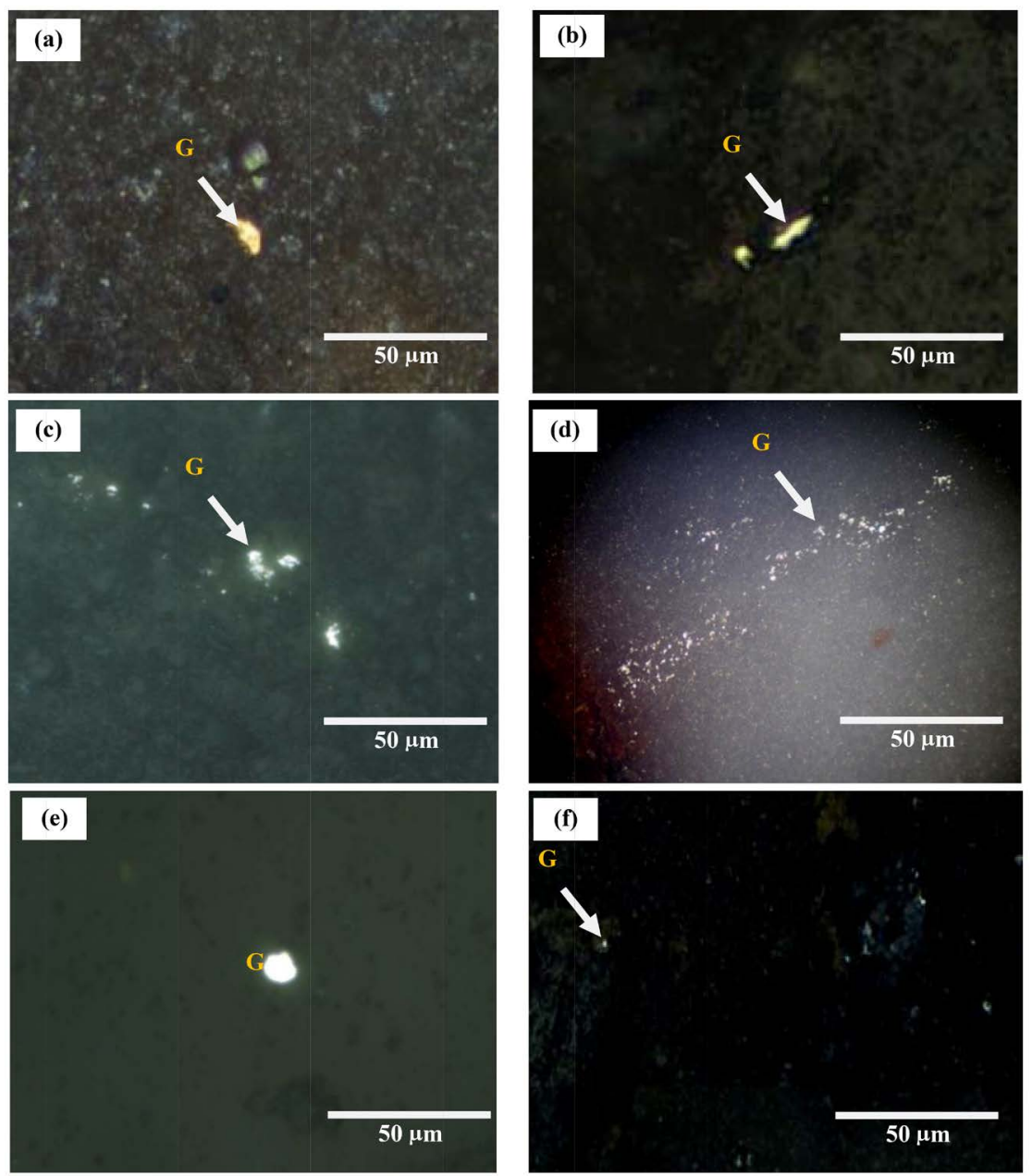

Figure 4. Photomicrograph of polished surface of the quartz vein sample showing: (a) Fine elongated speck of gold (G), associating with goethite; (b) Elongate crystals of gold enclosed in goethite after pyrite; (c), (d) Oriented fine specks and disseminations of gold filling the microfractures; (e) A photomicrograph of polished surface from the host rock samples showing anhedral grain of gold; (f) Very fine specks and disseminations of gold filling the microfractures.

(Figure 6(a)). Some chalcopyrite grains are variably altered to covellite and bornite forming progressive stages of rim-replacement texture from partial (Figure 6(b)) to complete replacement (Figure 6(c)). Fine-grained anhedral sphalerite and galena crystals exist scattered within the quartz veins (Figure 7(a), Figure $7(b))$. Isolated disseminated magnetite crystals occur within the alteration zone and host rock (Figure 8(a), Figure 8(b)) as well as embedded along peripheries, fractures and cleavages in altered biotite flakes (Figure 8(c), Figure 8(d)). Fine disseminations of ilmenite, titanomagnetite and rutile are recorded in the alteration zone (Figure 9). Magnetite and ilmenite partially altered to goethite and hematite. Any gold inclusions are not recorded in these minerals (Figure 10). This suggests the deposition of magnetite and ilmenite during magmatic segregation of the granodiorite.

Based on the mutual textural relationships and crystal morphology of the ore 
minerals the suggested paragenetic sequence of ore minerals forming El-Daghbag-I gold mineralization is shown in Figure 11.

\section{Geochemical Distribution of Gold and Associated Elements}

Table 1 shows the results of chemical analysis of the collected samples representing the main quartz vein, its alteration zones and the granodiorite host rock.
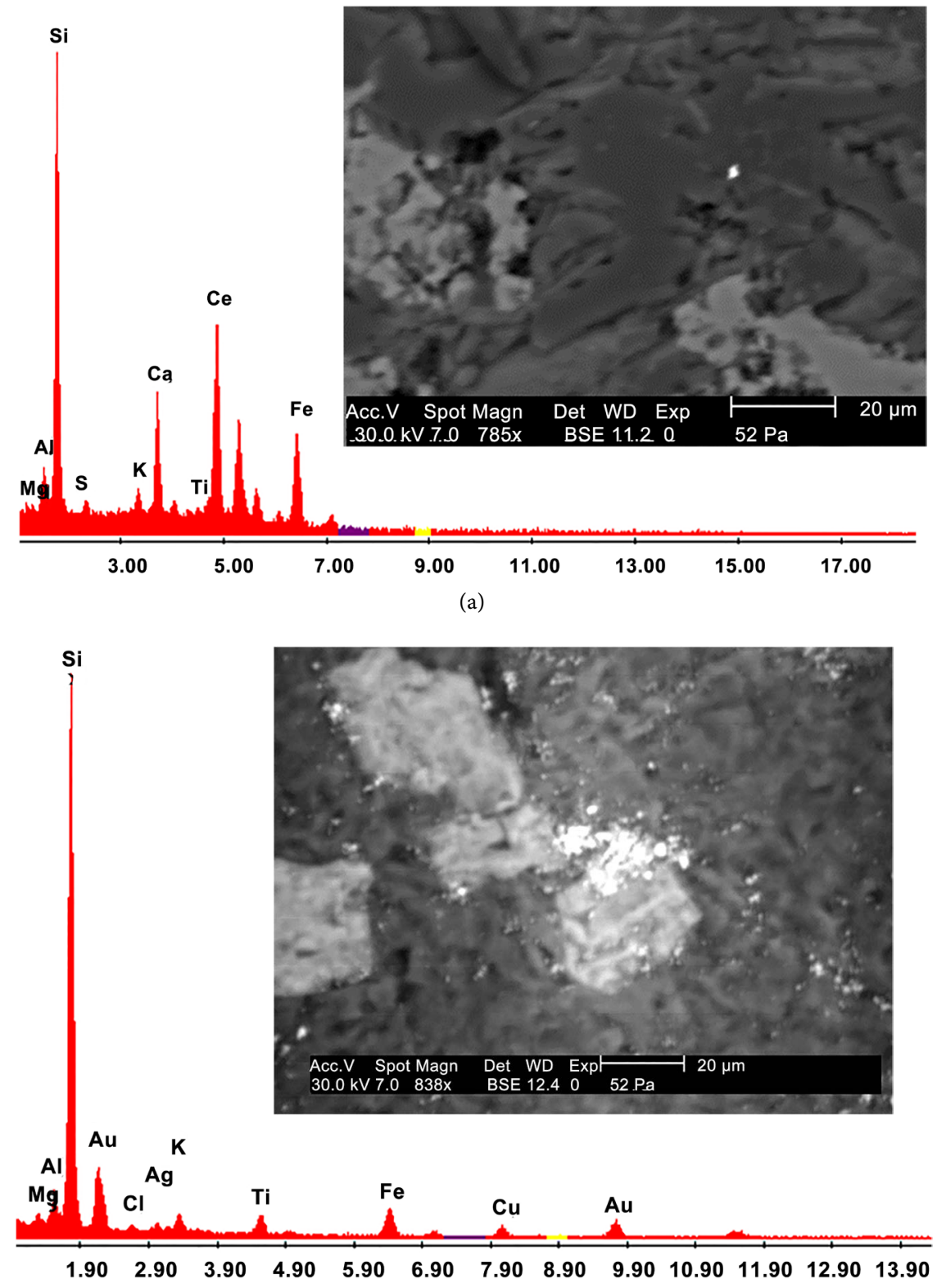

(b)

Figure 5. (a) An X-ray spectrum profile displaying the elements $\mathrm{Au}, \mathrm{Ag}, \mathrm{Cu}, \mathrm{Si}, \mathrm{Fe}, \mathrm{Mg}$, $\mathrm{Al}, \mathrm{Ti}, \mathrm{K}, \mathrm{Cl}$.The scan image shows the analyzed speck of gold in the alteration zone. The $\mathrm{Si}, \mathrm{Fe}, \mathrm{Mg}, \mathrm{Al}, \mathrm{Ti}, \mathrm{K}$ and $\mathrm{Cl}$ peaks are due to the groundmass; (b) An X-ray spectrum profile displaying the elements $\mathrm{Si}, \mathrm{Fe}, \mathrm{Mg}, \mathrm{Al}, \mathrm{Ti}, \mathrm{K}$ and $\mathrm{Ca}$. The scan image shows the analyzed pyrite remnants in goethite in the quartz vein. The $\mathrm{Si}, \mathrm{Mg}, \mathrm{Al}, \mathrm{Ti}, \mathrm{K}$ and $\mathrm{Ca}$ peaks are due to the groundmass. 

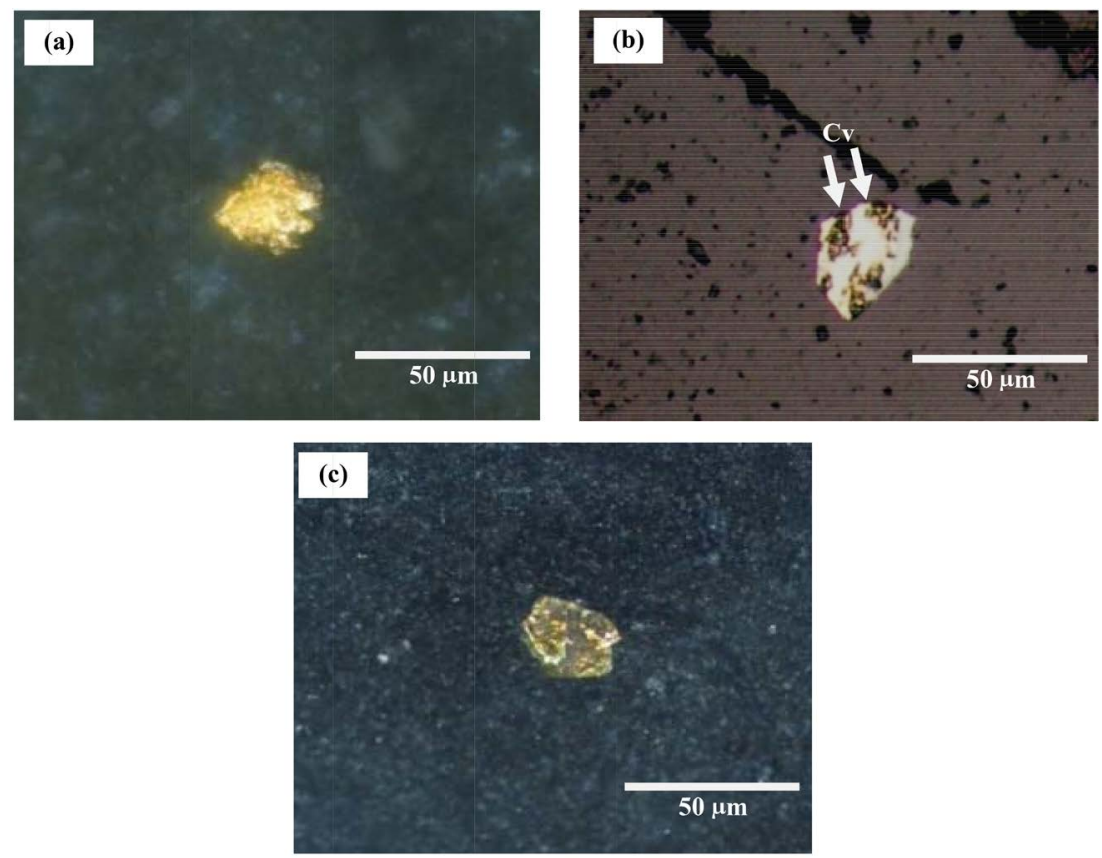

Figure 6. A photomicrograph of polished surface from the quartz vein showing: (a) Subhedral fine-grained chalcopyrite crystal; (b) Subhedral fine-grained chalcopyrite partially replaced by covellite $(\mathrm{Cv})$; (c) Fine-grained chalcopyrite completely replaced by covellite, R.P.L.

\subsection{Lithogeochemical Dispersion Patterns of the Elements in the Host Rocks}

1) The calculated statistical parameters for the recorded ore metals in the granodiorite hosting El-Daghbag-I gold mine given in (Table 2) show slight abnormal average contents of $\mathrm{Pb}, \mathrm{Co}, \mathrm{Cu}, \mathrm{Cr}$ and $\mathrm{Ni}$ compared to their averages in the high Ca-granites given by [32] and vice versa for Ag, As and $\mathrm{Zn}$ which could be considered characteristic feature for such granodiorite. Meanwhile, $\mathrm{Ag}, \mathrm{Cr}, \mathrm{Ni}$ and As contents show narrow range that reflected on the low values of S.D. and vice versa for $\mathrm{Zn}, \mathrm{Pb}, \mathrm{Cu}$ and $\mathrm{Co}$.

2) The calculated concentration clark (CC) values for the ore elements in the host rock (Table 3), using the reference content values of elements given by [32], show positive anomalous contents of only $\mathrm{Co}$ and $\mathrm{Cu}$ and vice versa for the other elements. However, $\mathrm{Cr}$ and Ni show slight abnormal content (3 times of high Ca-granites of [32]) to be considered geochemical characteristic for the host rock.

3) The computed correlation coefficient values of these elements for the host rocks given in Table 4 show presence of several correlation with each other as follows:

a) $\mathrm{Cu}$ shows positive significant and confident correlation with $\mathrm{Cr}$ and both are negatively correlated with As.

b) As is positively correlated with $\mathrm{Pb}$ and $\mathrm{Zn}$.

c) $\mathrm{Cu}$ is negatively correlated with $\mathrm{Pb}$ and $\mathrm{Zn}$ while both show strong significant confident correlation with each other. 
d) Ag-Co show negative significant and confident correlation at only p 0.07. These correlations can be expressed by the following formula:

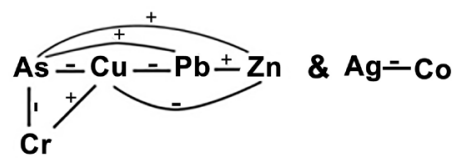

\subsection{Lithogeochemical Concentration Patterns of the Mineralization}

The gold content in 6 samples each 3 ones represent quartz vein and alteration

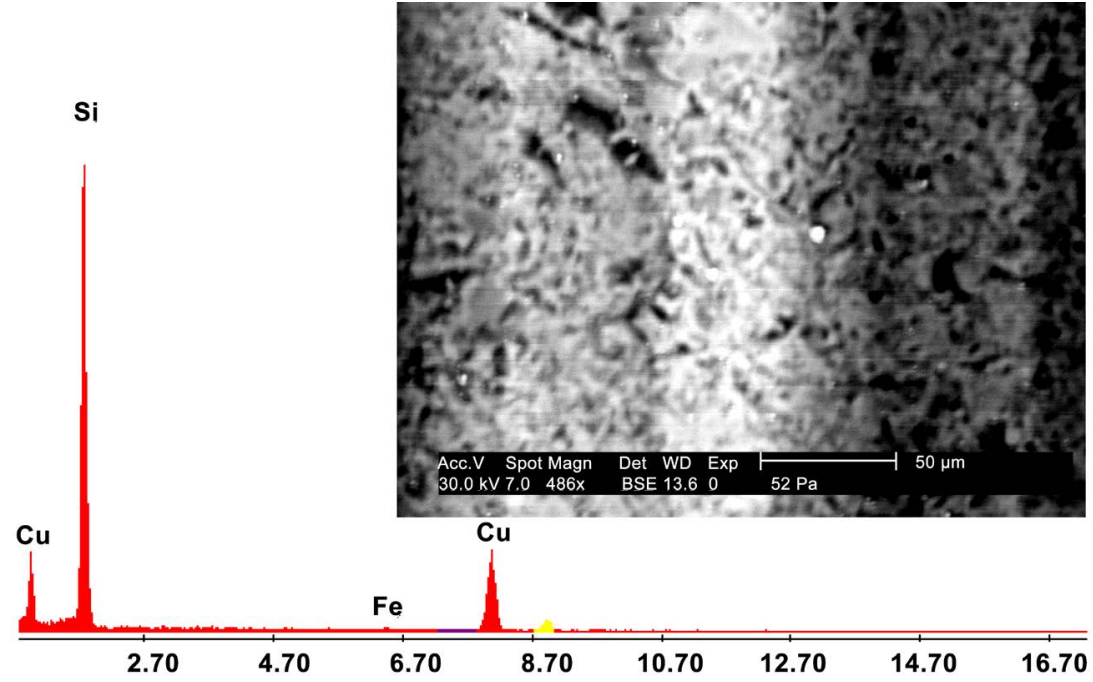

(a)

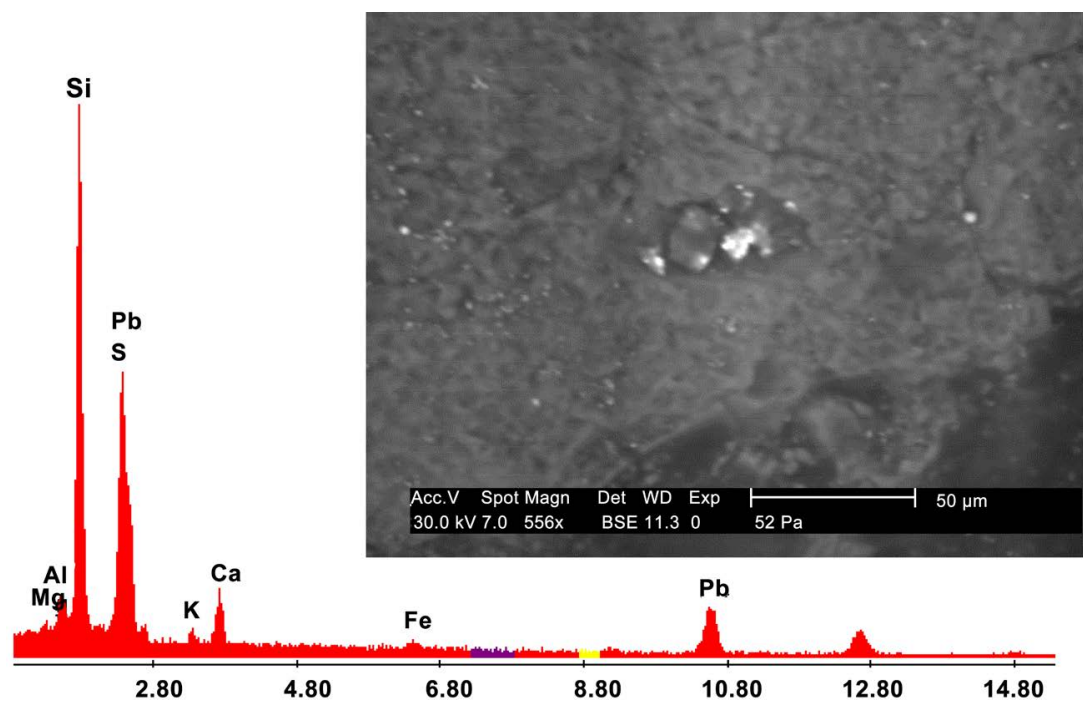

(b)

Figure 7. (a) An X-ray spectrum profile displaying the elements $\mathrm{Si}, \mathrm{Fe}$ and $\mathrm{Cu}$. The scan image shows the analyzed fine grain of chalcopyrite in the quartz vein. The $\mathrm{Si}$ is due to the groundmass; (b) An X-ray spectrum profile displaying the elements $\mathrm{Si}, \mathrm{Fe}$, $\mathrm{Ca}, \mathrm{Al}, \mathrm{Mg}, \mathrm{K}, \mathrm{Pb}$ and $\mathrm{S}$. The scan image shows the analyzed grains of galena in the quartz vein. The $\mathrm{Si}, \mathrm{Fe}, \mathrm{Ca}, \mathrm{Al}, \mathrm{Mg}$ and $\mathrm{K}$ are due to the groundmass. 

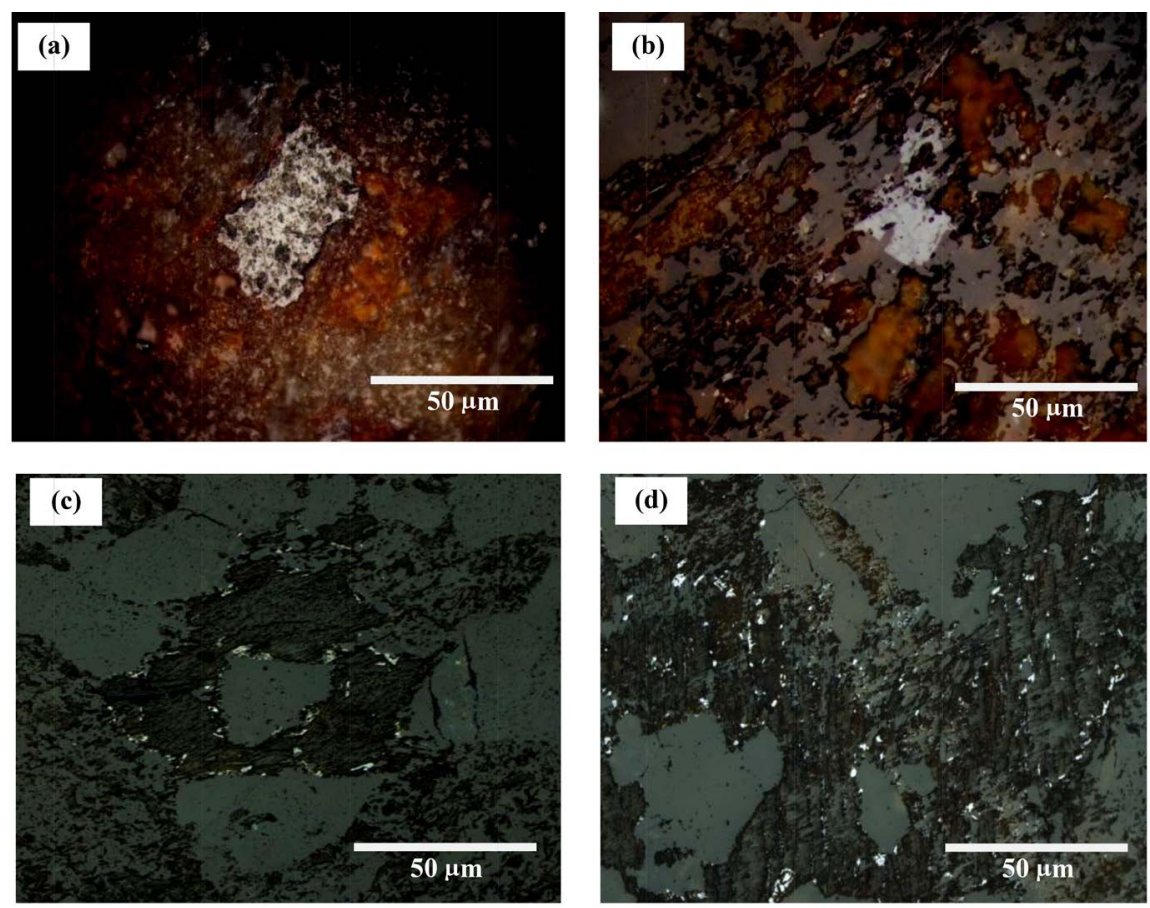

Figure 8. Photomicrograph of polished surface of the alteration zone samples showing: (a) (b) Fine disseminations of magnetite; (c) (d) Very fine grains of magnetite oriented along cleavage and peripheries of altered biotite.
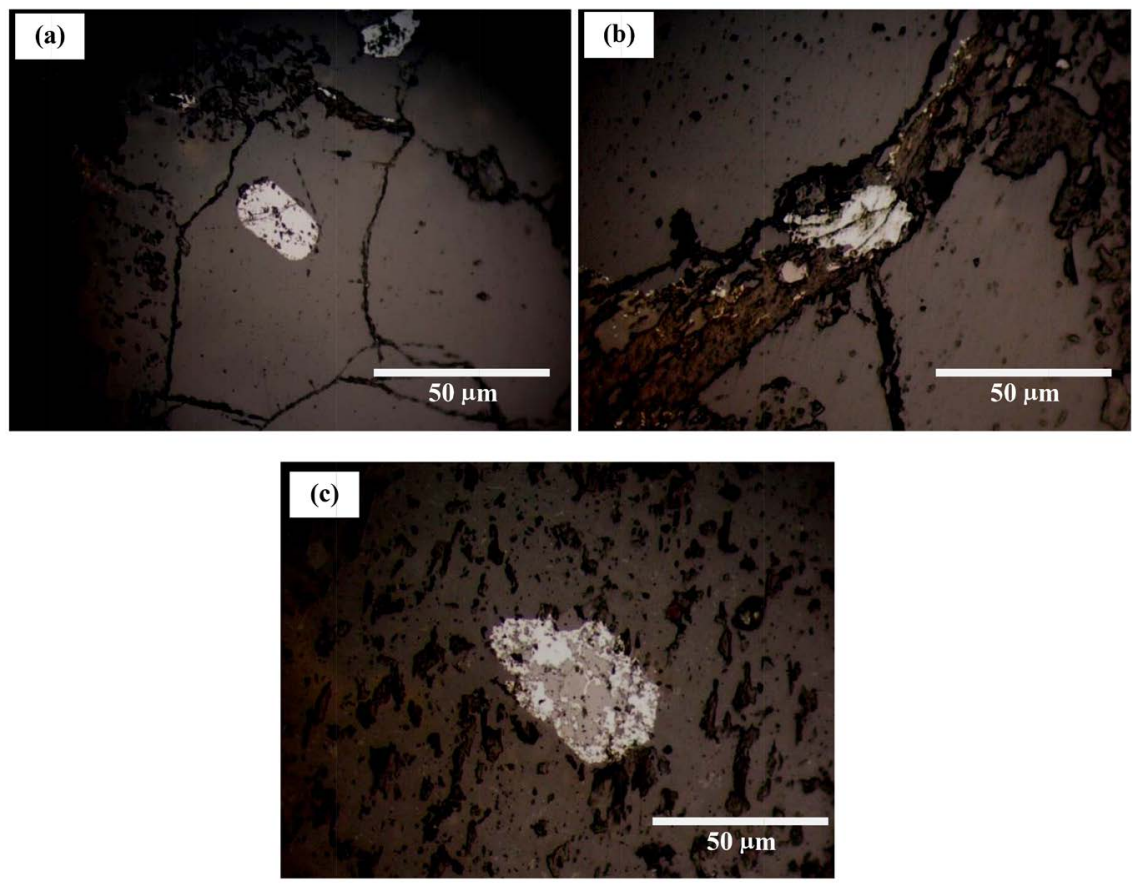

Figure 9. A photomicrograph of polished surface from the host granodiorite showing: (a) Fine dissimenated ilmenite crystal. (b) Titanomagnetite crystal filling fracture. (c) Dissimenated rutile crystal. R.P.L.

zone (Table 1) varies from a profile to another pointing to zonal distribution along the extension of the NW-SE trending mineralization. 


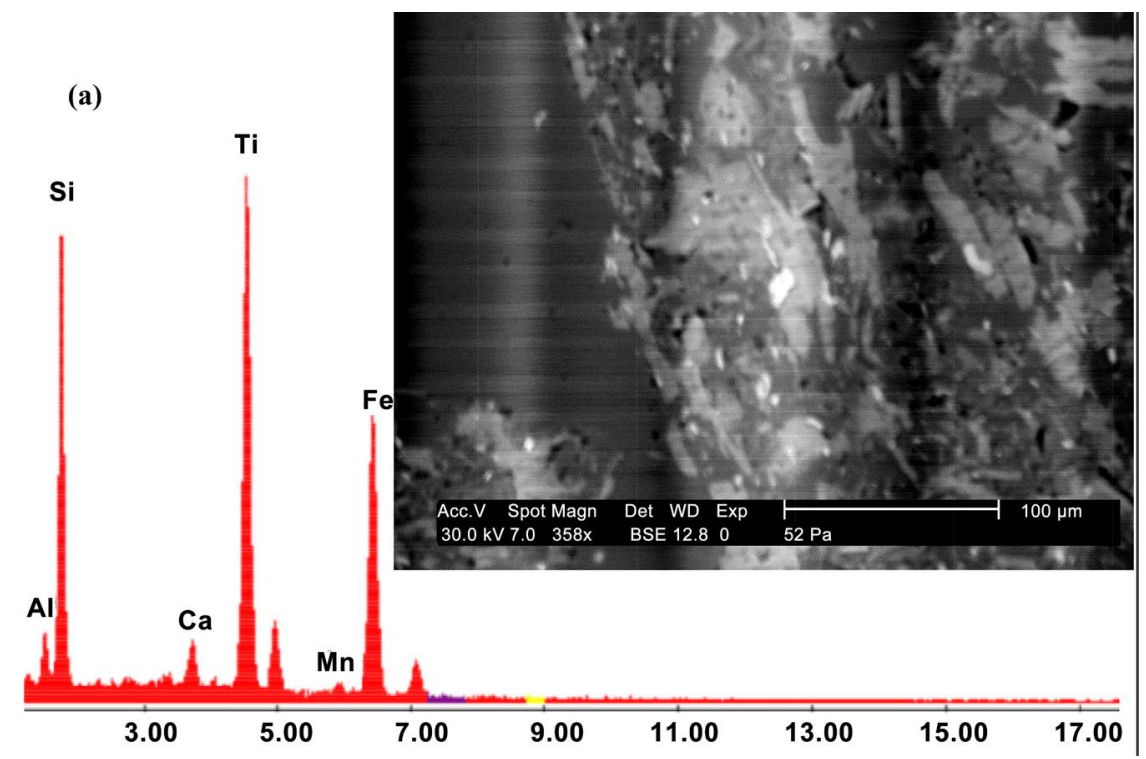

(a)

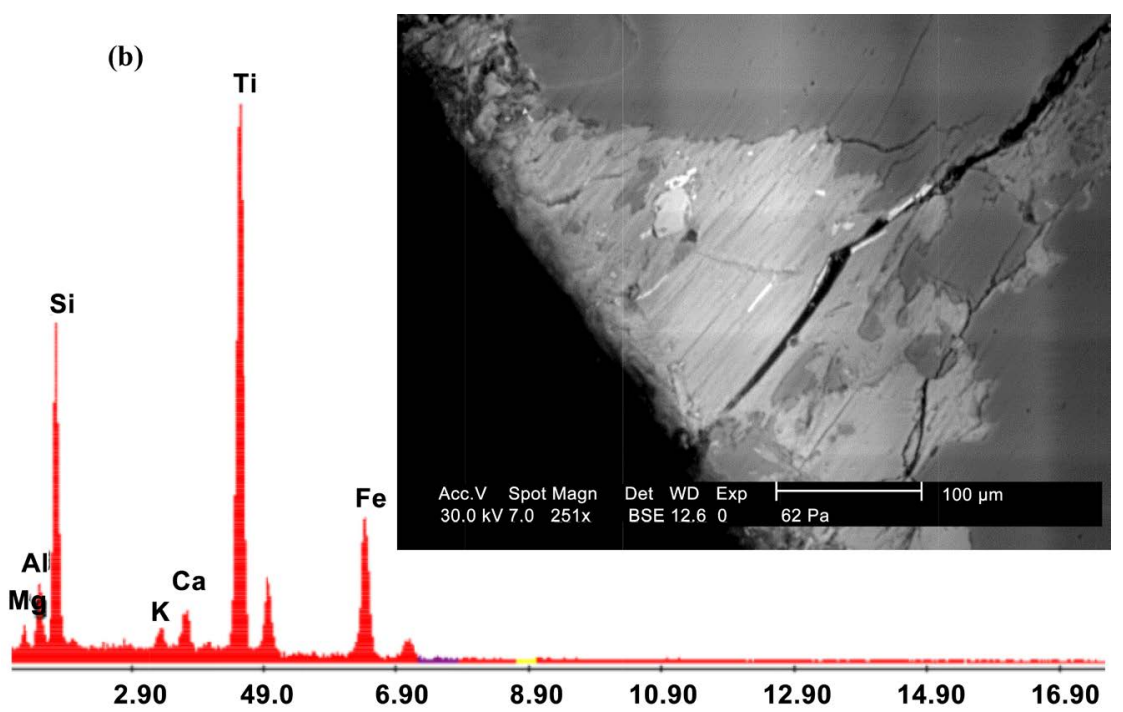

(b)

Figure 10. An X-ray spectrum profile displaying the elements $\mathrm{Ti}, \mathrm{Fe}, \mathrm{Si}, \mathrm{Mg}, \mathrm{Al}, \mathrm{K}$ and $\mathrm{Ca}$. The scan image shows the analyzed ilmenite crystals in the alteration zone. The $\mathrm{Si}$, $\mathrm{Mg}, \mathrm{Al}, \mathrm{K}$ and $\mathrm{Ca}$ peaks are due to the groundmass.

1) The calculated statistical parameters for the ore elements in the quartz vein and alteration zone samples given in Table 2 indicate higher Ag and $\mathrm{Cr}$ average contents of the quartz vein than those of the alteration zones and vice versa for As, $\mathrm{Pb}, \mathrm{Cu}, \mathrm{Ni}$ and $\mathrm{Zn}$.

2) Consequently, the high average content values of these ore elements in the quartz vein and the alteration zones enhance that they are the elements associating this mineralization.

3) The calculated concentration Clark (CC) values of $\mathrm{Au}, \mathrm{Ag}$ and $\mathrm{Cr}$ in the gold-bearing quartz veins are higher than those in the alteration zones and vice versa for $\mathrm{As}, \mathrm{Co}, \mathrm{Cu}, \mathrm{Ni}, \mathrm{Pb}$ and $\mathrm{Zn}$ (Table 3). The concentration Clark values 


\begin{tabular}{|c|c|c|}
\hline \multirow{2}{*}{ Mineral } & \multicolumn{2}{|l|}{ Stage } \\
\hline & Hydrothermal & Supergene \\
\hline Gold & ーーーーーーーーーーー & \\
\hline Pyrite & -ーーーー & \\
\hline Chaicopyrite & -ーーーー & \\
\hline Sphalerite & - & \\
\hline Galena & -שת- & \\
\hline Covellite & -ーー-ー & \\
\hline Bornite & -ேーー & \\
\hline Hematite & & -ーーーーーー \\
\hline Goethite & & \\
\hline
\end{tabular}

Figure 11. Paragenetic sequence of ore minerals associating El-Daghbag-I gold mineralization.

Table 1. Contents in ppm of ore elements in quartz vein, alteration zone and host rock, El-Daghbag-I gold mine. (not analyzed).

\begin{tabular}{|c|c|c|c|c|c|c|c|c|c|c|}
\hline Rock type & $\begin{array}{c}\text { Sample } \\
\text { No. }\end{array}$ & $\mathrm{Au}$ & $\mathrm{Ag}$ & As & Co & $\mathrm{Cu}$ & $\mathrm{Cr}$ & $\mathrm{Ni}$ & $\mathrm{Pb}$ & $\mathrm{Zn}$ \\
\hline \multirow{6}{*}{$\begin{array}{l}\text { Quartz } \\
\text { Veins }\end{array}$} & 1 & 0.98 & 0.1 & 303 & 5 & 10 & 23 & 7 & 445 & 84 \\
\hline & 2 & - & 0.1 & 1 & 4 & 11 & 29 & 5 & 7 & 12 \\
\hline & 3 & - & 0.01 & 1 & 1 & 11 & 27 & 4 & 3 & 9 \\
\hline & 4 & 2.2 & 1.2 & 1 & 5 & 11 & 24 & 5 & 10 & 19 \\
\hline & 5 & - & 0.8 & 58 & 6 & 11 & 27 & 7 & 83 & 118 \\
\hline & 6 & 1.34 & 2.1 & 18 & 5 & 10 & 23 & 4 & 31 & 23 \\
\hline \multirow{13}{*}{$\begin{array}{c}\text { Alteration } \\
\text { Zone }\end{array}$} & 7 & - & 0.49 & 953 & 7 & 46 & 10 & 16 & 3042 & 4257 \\
\hline & 8 & - & 0.01 & 256 & 6 & 38 & 11 & 10 & 650 & 57 \\
\hline & 9 & 0.8 & 0.38 & 623 & 3 & 33 & 10 & 11 & 1567 & 141 \\
\hline & 10 & - & 0.002 & 19 & 6 & 40 & 10 & 8 & 64 & 47 \\
\hline & 11 & - & 0.005 & 1 & 6 & 36 & 18 & 14 & 31 & 58 \\
\hline & 12 & - & 0.005 & 2 & 5 & 33 & 11 & 12 & n.d. & 37 \\
\hline & 13 & - & 0.002 & 2 & 4 & 34 & 11 & 10 & 27 & 36 \\
\hline & 14 & 0.72 & 0.02 & 60 & 7 & 32 & 18 & 18 & 115 & 26 \\
\hline & 15 & - & 0.003 & 2 & 9 & 45 & 49 & 35 & 32 & 41 \\
\hline & 16 & - & 0.002 & 2 & 6 & 27 & 14 & 20 & 60 & 43 \\
\hline & 17 & 2 & 0.11 & 220 & 4 & 36 & 10 & 9 & 583 & 256 \\
\hline & 18 & - & 0.01 & 98 & 9 & 31 & 12 & 11 & 251 & 116 \\
\hline & 19 & - & 0.01 & 40 & 2 & 31 & 14 & 13 & 170 & 59 \\
\hline \multirow{6}{*}{ Host rocks } & 20 & - & 0.002 & 1 & 5 & 34 & 13 & 10 & 23 & 50 \\
\hline & 21 & - & 0.001 & 1 & 8 & 32 & 12 & 9 & 10 & 41 \\
\hline & 22 & - & 0.004 & 1 & 2 & 35 & 12 & 11 & 11 & 44 \\
\hline & 23 & - & 0.002 & 3 & 6 & 25 & 10 & 7 & 57 & 79 \\
\hline & 24 & - & 0.001 & 1 & 13 & 30 & 11 & 10 & 16 & 41 \\
\hline & 25 & - & 0.002 & 1 & 1 & 38 & 12 & 6 & 8 & 39 \\
\hline
\end{tabular}


Table 2. Statistical parameters for ore elements in quartz vein, alteration zone and host rock, El-Daghbag-I gold mine.

\begin{tabular}{cccccccccc}
\hline Rock Type & $\begin{array}{c}\text { Statistical } \\
\text { Parameter }\end{array}$ & $\mathrm{Zn}$ & $\mathrm{Ag}$ & $\mathrm{As}$ & $\mathrm{Cu}$ & $\mathrm{Pb}$ & $\mathrm{Cr}$ & $\mathrm{Ni}$ & $\mathrm{Co}$ \\
& Min. & 9 & 0.01 & 1 & 10 & 3 & 23 & 4 & 1 \\
Quartz & Max. & 118 & 2.1 & 303 & 11 & 445 & 29 & 7 & 6 \\
veins & Average & 44 & 0.7 & 63.67 & 11 & 97 & 26 & 5 & 4 \\
(n=6) & S.D & 46 & 0.8 & 119.31 & 1 & 173 & 3 & 1 & 2 \\
& V.C & 1.05 & 1.14 & 1.87 & 0.09 & 1.78 & 0.12 & 0.2 & 0.5 \\
\hline \multirow{4}{*}{ Alteration } & Min. & 26 & 0.002 & 1 & 27 & 12 & 10 & 8 & 2 \\
zones & Max. & 4257 & 0.49 & 953 & 46 & 3042 & 49 & 35 & 9 \\
Average & 398 & 0.08 & 175.23 & 35.5 & 508 & 15 & 14.4 & 5.7 \\
& S.D & 1161 & 0.16 & 292.44 & 5.5 & 877.1 & 11 & 7.1 & 2.1 \\
& V.C & 2.9 & 2 & 1.67 & 0.16 & 1.73 & 0.73 & 0.49 & 0.37 \\
\hline & Min. & 39 & 0.001 & 1 & 25 & 8 & 10 & 6 & 1 \\
Host rocks & Max. & 79 & 0.004 & 3 & 38 & 57 & 13 & 11 & 13 \\
(n=6) & Average & 49 & 0.002 & 1.33 & 32.3 & 20.8 & 12 & 8.8 & 5.8 \\
& S.D & 15.2 & - & 0.82 & 4.5 & 18.5 & 1 & 1.9 & 4.4 \\
& V.C & 0.31 & - & 0.62 & 0.14 & 0.89 & 0.08 & 0.22 & 0.76 \\
\hline
\end{tabular}

$\mathrm{n}=$ number of samples.

for $\mathrm{Au} \mathrm{Ag}, \mathrm{As}, \mathrm{Co}, \mathrm{Cr}, \mathrm{Cu}$ and $\mathrm{Pb}$ in the quartz veins are positively anomalous while $\mathrm{Ni}$ shows $\mathrm{CC}$ values in normal range and $\mathrm{Zn}$ shows $\mathrm{CC}$ values less than 1.0. In the alteration zone, the $\mathrm{CC}$ values for gold, $\mathrm{Ag}, \mathrm{As}, \mathrm{Co}, \mathrm{Cr}, \mathrm{Cu}, \mathrm{Ni}, \mathrm{Pb}$ and $\mathrm{Zn}$ are positively anomalous favoring that they are the associated elements of the mineralization. The Concentration Clark values of the ore elements (Table 3) and the plotted values along each profile (Figure 12) show variable values with the same profile as well as from profile I to profile III. This favors presence of zonal distribution along each profile trending NE-SW and along the NW-SE trend of the mineralization zone from its northern to southern part.

The correlation coefficient values between the ore elements for the quartz veins (Table 5) point to that there are three groups of elements, in each of which the elements are significantly positively correlated $(r \geq 0.70)$. These groups are $(\mathrm{Cu}, \mathrm{Cr}),(\mathrm{Ni}, \mathrm{Zn}),(\mathrm{As}, \mathrm{Ni}, \mathrm{Pb})$. The (As- $\mathrm{Pb})$ is very strongly correlated, where its $\mathrm{r}$ values is 1 . The pair (Ni-Zn) is strongly correlated, where $0.83>r \geq 0.93$. The $(\mathrm{Cu}, \mathrm{Cr})$ and $(\mathrm{Ni}, \mathrm{Pb})$ pairs of elements within these groups show fair relationship, $0.70>r \geq 0.83$. These relationships between the correlated elements can be expressed by the following formula:

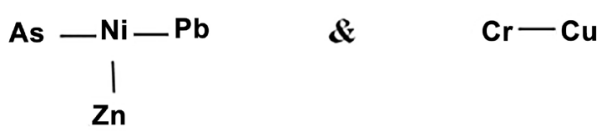

The $(r)$ values for the elements in the alteration zone samples shown in (Table 6) point to presence of three groups of elements in each of which the elements 
Table 3. The Concentration Clark values for ore elements in the analyzed samples from El-Daghbag-I gold mine area.

\begin{tabular}{|c|c|c|c|c|c|c|c|c|c|c|c|}
\hline $\begin{array}{c}\text { Profile } \\
\text { No. }\end{array}$ & S. No. & Type & $\mathrm{Au}$ & $\mathrm{Ag}$ & As & Co & $\mathrm{Cu}$ & $\mathrm{Cr}$ & $\mathrm{Ni}$ & $\mathrm{Pb}$ & $\mathrm{Zn}$ \\
\hline \multirow{2}{*}{ SW } & 11 & Al. Z. & - & 0.1 & 0.7 & 6 & 7 & 4 & 4 & 3 & 0.5 \\
\hline & 10 & Al. Z. & - & 0.04 & 14 & 6 & 8 & 2 & 2 & 5 & 0.4 \\
\hline \multirow{4}{*}{ PI } & 9 & Al. Z. & 200 & 7.6 & 445 & 3 & 7 & 2 & 3 & 131 & 1 \\
\hline & 1 & Q. V. & 245 & 2 & 216 & 5 & 2 & 6 & 2 & 37 & 1 \\
\hline & 7 & Al. Z. & - & 9.8 & 681 & 7 & 9 & 2 & 4 & 254 & 33 \\
\hline & 8 & Al. Z. & - & 0.2 & 183 & 6 & 8 & 3 & 3 & 54 & 0.4 \\
\hline \multirow{2}{*}{$\mathrm{NE}$} & 20 & H. R. & - & 0.04 & 0.7 & 5 & 7 & 3 & 3 & 2 & 0.4 \\
\hline & 21 & H. R. & - & 0.02 & 0.7 & 8 & 6 & 3 & 3 & 1 & 0.3 \\
\hline \multirow{2}{*}{ sW } & 25 & H. R. & - & 0.04 & 0.7 & 1 & 8 & 3 & 2 & 1 & 0.3 \\
\hline & 16 & Al. Z. & - & 0.04 & 1.4 & 6 & 5 & 3 & 5 & 5 & 0.3 \\
\hline \multirow{6}{*}{ PII } & 15 & Al. Z. & - & 0.06 & 1.4 & 9 & 9 & 12 & 9 & 3 & 0.3 \\
\hline & 14 & Al. Z. & 180 & 0.4 & 43 & 7 & 6 & 4 & 5 & 10 & 0.2 \\
\hline & 4 & Q. V. & 550 & 24 & 0.7 & 5 & 2 & 6 & 1 & 0.8 & 0.2 \\
\hline & 3 & Q. V. & - & 0.2 & 0.7 & 1 & 2 & 7 & 1 & 0.3 & 0.1 \\
\hline & 2 & Q. V. & - & 2 & 0.7 & 4 & 2 & 7 & 1 & 1 & 0.1 \\
\hline & 13 & Al. Z. & - & 0.04 & 0.7 & 4 & 7 & 3 & 3 & 2 & 0.3 \\
\hline \multirow{2}{*}{$\mathrm{NE}$} & 12 & Al. Z. & - & 0.1 & 0.7 & 5 & 7 & 3 & 3 & - & 0.3 \\
\hline & 22 & H. R. & - & 0.08 & 0.7 & 2 & 7 & 3 & 3 & 1 & 0.3 \\
\hline \multirow{2}{*}{ SW } & 24 & H. R. & - & 0.02 & 0.7 & 13 & 6 & 3 & 3 & 1 & 0.3 \\
\hline & 17 & Al. Z. & 500 & 2.2 & 157 & 4 & 7 & 2 & 2 & 49 & 2 \\
\hline \multirow{4}{*}{ PIII } & 6 & Q. V. & 335 & 42 & 13 & 5 & 2 & 6 & 1 & 3 & 0.2 \\
\hline & 5 & Q. V. & - & 16 & 41 & 6 & 2 & 7 & 2 & 7 & 1 \\
\hline & 18 & Al. Z. & - & 0.2 & 70 & 9 & 6 & 3 & 3 & 21 & 1 \\
\hline & 19 & Al. Z. & - & 0.2 & 29 & 2 & 6 & 3 & 3 & 14 & 0.5 \\
\hline $\mathrm{NE}$ & 23 & H. R. & - & 0.04 & 2 & 6 & 5 & 2 & 2 & 5 & 0.6 \\
\hline
\end{tabular}

Q. V. = quartz vein, Al. Z. = alteration zone, H. R. = host rock.

Table 4. Correlation coefficient values between ore associated elements in the host rock, El-Daghbag-I gold mine.

\begin{tabular}{cccccccc}
\hline & $\mathrm{Ag}$ & $\mathrm{Pb}$ & $\mathrm{Zn}$ & $\mathrm{Cu}$ & $\mathrm{Ni}$ & $\mathrm{Cr}$ & $\mathrm{Co}$ \\
\hline $\mathrm{As}$ & 0.00 & 0.96 & 0.97 & -0.80 & -0.46 & -0.79 & 0.02 \\
$\mathrm{Co}$ & -0.71 & 0.11 & -0.01 & -0.59 & 0.30 & -0.37 & \\
$\mathrm{Cr}$ & 0.18 & -0.68 & -0.65 & 0.80 & 0.37 & & \\
$\mathrm{Ni}$ & 0.28 & -0.31 & -0.32 & 0.05 & & & \\
$\mathrm{Cu}$ & 0.32 & -0.83 & -0.78 & & & \\
$\mathrm{Zn}$ & 0.07 & 0.99 & & & & \\
$\mathrm{~Pb}$ & -0.04 & & & & & \\
\hline
\end{tabular}

No. of samples $=6, \mathrm{r}=0.7$ at $\mathrm{P}=0.05, \mathrm{r}=0.83$ at $\mathrm{P}=0.01, \mathrm{r}=0.93$ at $\mathrm{P}=0.001$

are significantly positive correlated $(\mathrm{r} \geq 0.54)$. These groups are ( $\mathrm{Pb}, \mathrm{Zn}, \mathrm{As}, \mathrm{Ag})$, $(\mathrm{Zn}, \mathrm{Cu})$ and $(\mathrm{Ni}, \mathrm{Cr})$ as expressed by the following formula: 

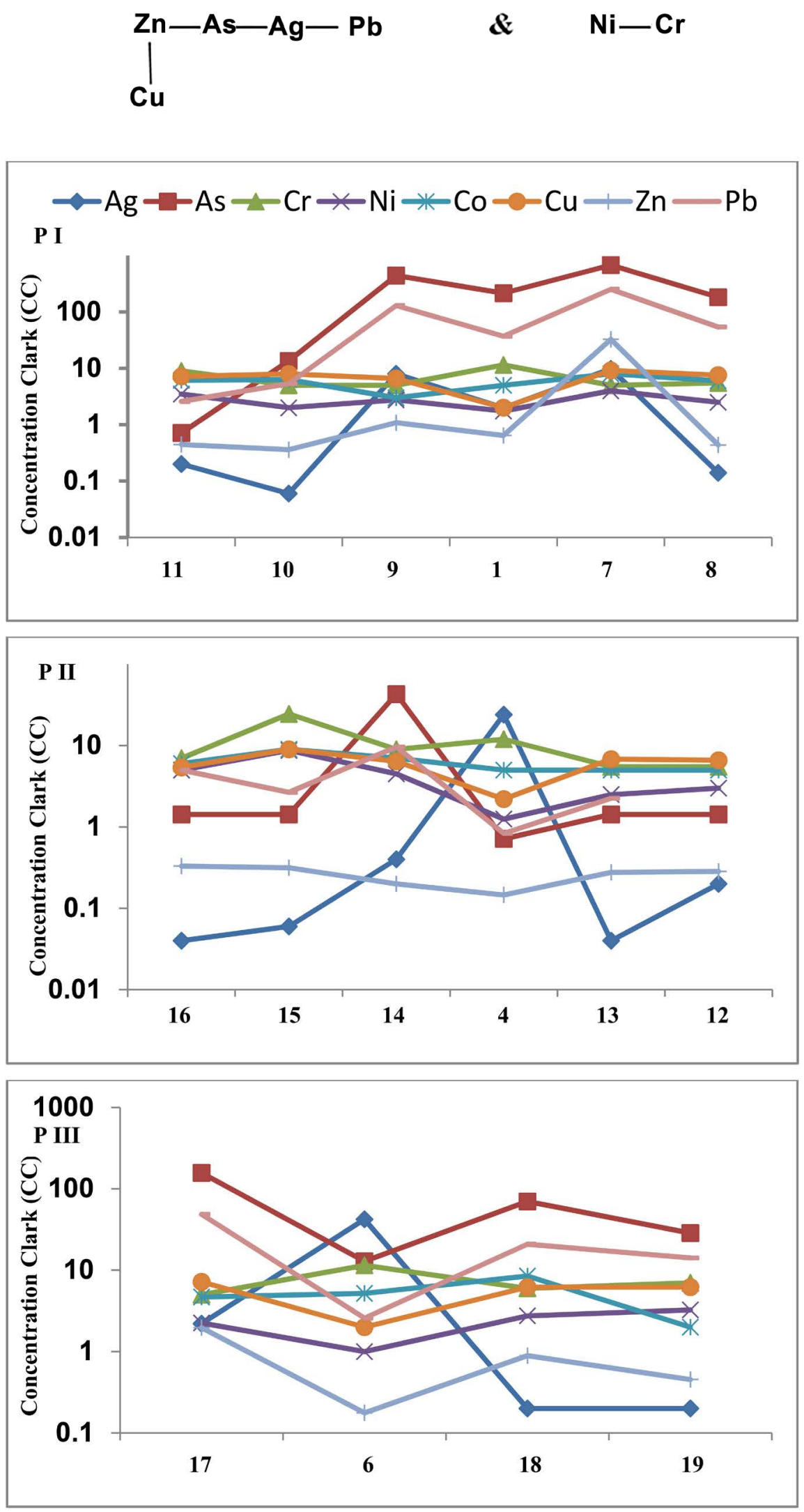

Figure 12. Concentration Clark (CC) values along the profiles (PI, PII and PIII), El-Daghbag-I gold mine. 
Table 5. Correlation coefficient values between gold and associated elements in quartz veins, El-Daghbag-I gold mine.

\begin{tabular}{cccccccc}
\hline & $\mathrm{Cr}$ & $\mathrm{Ni}$ & $\mathrm{Co}$ & $\mathrm{Cu}$ & $\mathrm{Pb}$ & $\mathrm{Zn}$ & $\mathrm{Ag}$ \\
\hline $\mathrm{As}$ & -0.48 & 0.71 & 0.29 & -0.63 & 1.00 & 0.58 & -0.32 \\
$\mathrm{Ag}$ & -0.55 & -0.31 & 0.49 & -0.36 & -0.32 & -0.08 & \\
$\mathrm{Zn}$ & -0.11 & 0.91 & 0.62 & -0.16 & 0.57 & & \\
$\mathrm{~Pb}$ & -0.48 & 0.70 & 0.30 & -0.63 & & & \\
$\mathrm{Cu}$ & 0.77 & -0.09 & -0.29 & & & & \\
$\mathrm{Co}$ & -0.36 & 0.61 & & & & & \\
$\mathrm{Ni}$ & -0.06 & & & & & & \\
\hline
\end{tabular}

No. of samples $=6, \mathrm{r}=0.7$ at $\mathrm{P}=0.05, \mathrm{r}=0.83$ at $\mathrm{P}=0.01, \mathrm{r}=0.93$ at $\mathrm{P}=0.001$.

Table 6. Correlation coefficient values between gold and associated elements in alteration zones, El-Daghbag-I gold mine.

\begin{tabular}{cccccccc}
\hline & $\mathrm{Pb}$ & $\mathrm{Zn}$ & $\mathrm{Cu}$ & $\mathrm{Ni}$ & $\mathrm{Cr}$ & $\mathrm{Co}$ & $\mathrm{Ag}$ \\
\hline $\mathrm{As}$ & 0.99 & 0.82 & 0.43 & -0.13 & -0.29 & -0.06 & 0.97 \\
$\mathrm{Ag}$ & 0.96 & 0.78 & 0.38 & -0.08 & -0.25 & -0.13 & \\
$\mathrm{Co}$ & -0.03 & 0.17 & 0.37 & 0.53 & 0.50 & & \\
$\mathrm{Cr}$ & -0.27 & -0.16 & 0.40 & 0.92 & & & \\
$\mathrm{Ni}$ & -0.09 & 0.05 & 0.32 & & & & \\
$\mathrm{Cu}$ & 0.46 & 0.57 & & & & & \\
$\mathrm{Zn}$ & 0.88 & & & & & & \\
\hline
\end{tabular}

No. of samples $=12, \mathrm{r}=0.55$ at $\mathrm{P}=0.05 . \mathrm{r}=0.68$ at $\mathrm{P}=0.01, \mathrm{r}=0.8$ at $\mathrm{P}=0.001$.

The pairs (As- $\mathrm{Ag}),(\mathrm{As}-\mathrm{Pb}),(\mathrm{Ag}-\mathrm{Pb}),(\mathrm{Zn}-\mathrm{Pb}),(\mathrm{Zn}-\mathrm{As})$ and $(\mathrm{Ni}-\mathrm{Cr})$ are very strongly correlated $(r \geq 0.8)$. The pair $(\mathrm{Ag}-\mathrm{Zn})$ is strongly correlated $(0.8>\mathrm{r} \geq$ $0.68)$ while $(\mathrm{Zn}-\mathrm{Cu})$ is fairly correlated $(0.68>\mathrm{r} \geq 0.55)$.

From studying both distribution patterns of El-Daghbag-I gold mineralization, it is clear that the ore elements $\mathrm{Ag}, \mathrm{As}, \mathrm{Co}, \mathrm{Cu}, \mathrm{Cr}, \mathrm{Ni}, \mathrm{Pb}$ and $\mathrm{Zn}$ form the geochemical association of the mineralization. The recorded significant correlation coefficient values between these ore elements favor existence of these elements either in proper ore minerals recorded by microscopic studies and/or incorporated within the crystal lattice of these sulfide minerals.

\subsection{Lateral Zoning}

The linear productivity, contrast coefficient, geochemical zonality index and zoning coefficient values were calculated and used to investigate the lateral zoning of ore elements in the area of El-Daghbag-I gold mine. Tables 7-10 show these values throughout the (NW-SE) and (NE-SW) profiles.

The arrangement of linear productivity, contrast coefficient and zonality index values in decreasing order from NW to SE (parallel to the quartz vein extension) gives the following sequences: 
Table 7. Linear productivity values $(\mathrm{M})$ and contrast coefficient of gold associated elements of the profiles (PI, PII and PIII), El-Daghbag-I gold mine.

\begin{tabular}{ccccc}
\hline & \multicolumn{3}{c}{ Linear productivity (M) } & Contrast \\
\cline { 2 - 4 } & PI & PII & PIII & coefficient \\
(NW) & (Central) & (SE) & \\
\hline $\mathrm{Ag}$ & 0.5 & 0.7 & 1.5 & 0.33 \\
$\mathrm{As}$ & 1077 & 31 & 217 & 4.96 \\
$\mathrm{Cr}$ & 41 & 91.5 & 43 & 0.95 \\
$\mathrm{Ni}$ & 33 & 54.5 & 22 & 1.5 \\
$\mathrm{Co}$ & 10.2 & 21 & 13.3 & 0.77 \\
$\mathrm{Cu}$ & 101.5 & 102 & 59.5 & 1.71 \\
$\mathrm{Zn}$ & 2322 & 111.5 & 286 & 8.12 \\
$\mathrm{~Pb}$ & 2899.5 & 127 & 559 & 5.19 \\
$\mathrm{Total}$ & 6484.7 & 539.2 & 1201.3 & \\
\hline
\end{tabular}

Table 8. Zonality indices of gold and associated elements along the (NW-SE) direction, El-Daghbag-I gold mine.

\begin{tabular}{cccc}
\hline & \multicolumn{3}{c}{ Zonality Index } \\
\cline { 2 - 4 } & $\mathrm{PI}$ & $\begin{array}{c}\text { PII } \\
(\text { Central })\end{array}$ & $\begin{array}{c}\text { PIII } \\
(\text { SE })\end{array}$ \\
\hline $\mathrm{Ag}$ & $7.71 \mathrm{E}-05$ & 0.00129 & 0.00124 \\
$\mathrm{As}$ & 0.166 & 0.058 & 0.181 \\
$\mathrm{Cr}$ & 0.006 & 0.170 & 0.036 \\
$\mathrm{Ni}$ & 0.005 & 0.101 & 0.018 \\
$\mathrm{Co}$ & 0.002 & 0.039 & 0.011 \\
$\mathrm{Cu}$ & 0.016 & 0.189 & 0.045 \\
$\mathrm{Zn}$ & 0.358 & 0.207 & 0.238 \\
$\mathrm{~Pb}$ & 0.447 & 0.236 & 0.465 \\
\hline
\end{tabular}

Table 9. Linear productivity and contrast coefficient values of the ore elements perpendicular to the extension of the mineralization (SW-NE), El-Daghbag-I gold mine.

\begin{tabular}{ccccc}
\hline & SW & Linear productivity (M) & $\mathrm{NE}$ & $\begin{array}{c}\text { Contrast } \\
\text { Coefficient }\end{array}$ \\
\cline { 2 - 4 } & $\mathrm{AZ}$ & $\mathrm{Qz} \mathrm{V}$ & $\mathrm{AZ}$ & 0.43 \\
$\mathrm{Ag}$ & 5.8 & 73.1 & 13.5 & 0.37 \\
$\mathrm{As}$ & 11211 & 12641.7 & 30506.5 & 1.67 \\
$\mathrm{Cr}$ & 1948.7 & 2762.7 & 1165.5 & 1.43 \\
$\mathrm{Ni}$ & 1751.3 & 635.2 & 1221 & 0.78 \\
$\mathrm{Co}$ & 483.3 & 517.4 & 617.9 & 0.92 \\
$\mathrm{Cu}$ & 3774 & 1165.5 & 4125.5 & 0.08 \\
$\mathrm{Zn}$ & 7628.2 & 6209.8 & 90631.5 & 0.34 \\
$\mathrm{~Pb}$ & 30839.5 & 18820.7 & 90372.5 & \\
Total & 57641.8 & 42826.1 & 218653.9 & \\
\hline
\end{tabular}


Table 10. Zonality indices of the ore elements along the (SW-NE) direction, El-Daghbag-I gold mine.

\begin{tabular}{cccc}
\hline & SW & Zonality Index & NE \\
\cline { 2 - 4 } & $\mathrm{AZ}$ & $\mathrm{Qz} \mathrm{V}$ & $\mathrm{AZ}$ \\
\hline $\mathrm{Ag}$ & 0.0001 & 0.002 & $6.2 \mathrm{E}-05$ \\
$\mathrm{As}$ & 0.195 & 0.295 & 0.14 \\
$\mathrm{Cr}$ & 0.034 & 0.065 & 0.005 \\
$\mathrm{Ni}$ & 0.030 & 0.015 & 0.006 \\
$\mathrm{Co}$ & 0.008 & 0.012 & 0.003 \\
$\mathrm{Cu}$ & 0.0656 & 0.027 & 0.019 \\
$\mathrm{Zn}$ & 0.132 & 0.145 & 0.415 \\
$\mathrm{~Pb}$ & 0.535 & 0.44 & 0.413 \\
\hline
\end{tabular}

$\begin{array}{ll}\text { Linear productivity } & (\mathrm{As}, \mathrm{Zn}, \mathrm{Pb})-(\mathrm{Cr}, \mathrm{Ni}, \mathrm{Co}, \mathrm{Cu})-\mathrm{Ag} \\ \text { Contrast coefficient } & \mathrm{Zn}-\mathrm{Pb}-\mathrm{As}-\mathrm{Cu}-\mathrm{Ni}-\mathrm{Cr}-\mathrm{Co}-\mathrm{Ag} \\ \text { Zonality index } & \mathrm{Zn}-(\mathrm{Ag}, \mathrm{Cr}, \mathrm{Ni}, \mathrm{Co}, \mathrm{Cu})-(\mathrm{As}, \mathrm{Pb})\end{array}$

Moreover, arrangement of values of these factors in decreasing order from SW to NE (perpendicular to extension of the quartz vein) gives the following sequences:

$$
\begin{array}{ll}
\text { Linear productivity } & \mathrm{Ni}-(\mathrm{Ag}, \mathrm{Cr})-(\mathrm{As}, \mathrm{Co}, \mathrm{Cu}, \mathrm{Zn}, \mathrm{Pb}) \\
\text { Contrast coefficient } & \mathrm{Cr}-\mathrm{Ni}-\mathrm{Cu}-\mathrm{Co}-\mathrm{Ag}-\mathrm{Pb}-\mathrm{As}-\mathrm{Zn} \\
\text { Zonality index } & (\mathrm{Ni}, \mathrm{Cu}, \mathrm{Pb})-(\mathrm{Ag}, \mathrm{As}, \mathrm{Cr}, \mathrm{Co})-\mathrm{Zn}
\end{array}
$$

Table 7 and the plotted diagram of the linear productivity versus the extension of the mineralized zone (Figure 13) show that the $\mathrm{Ag}(\mathrm{M})$ values increase southward at profile III and vice versa for $\mathrm{Pb}, \mathrm{Zn}$ and $\mathrm{As}$ while those for $\mathrm{Co}, \mathrm{Ni}$, $\mathrm{Cr}$ and $\mathrm{Cu}$ are high in the central part than the northern and southern parts of the lode and associated alteration zones. Table 9 and Figure 14 show that the $\mathrm{Pb}, \mathrm{Zn}$ and $\mathrm{As} \mathrm{M}$ values highly increase from the western towards the eastern alteration zones via quartz vein while the $\mathrm{Cu}$ and $\mathrm{Co} M$ values show slight increase.

The calculated zoning coefficient values along the NW-SE and SW-NE directions were plotted versus the lateral distance (Figure 15, Figure 16). The arrangement of regression lines for these plotted values in the NW-SE and SW-NE directions give the following lateral zoning sequences:

\section{From NW to SE Ag-Co-Ni-Cr-Cu-As-Zn-Pb \\ From SW to NE Ag-Co-Cr-Ni-Cu-As-Pb-Zn}

\section{Discussion}

The gold mineralization at El-Daghbag-I gold mine is represented by several NW-trending quartz veins cutting across highly sheared granodioritic rocks along NW-trending shear zone. The recorded primary ore minerals forming the assemblage of El-Daghbag-I gold mineralization is magnetite, ilmenite, native 


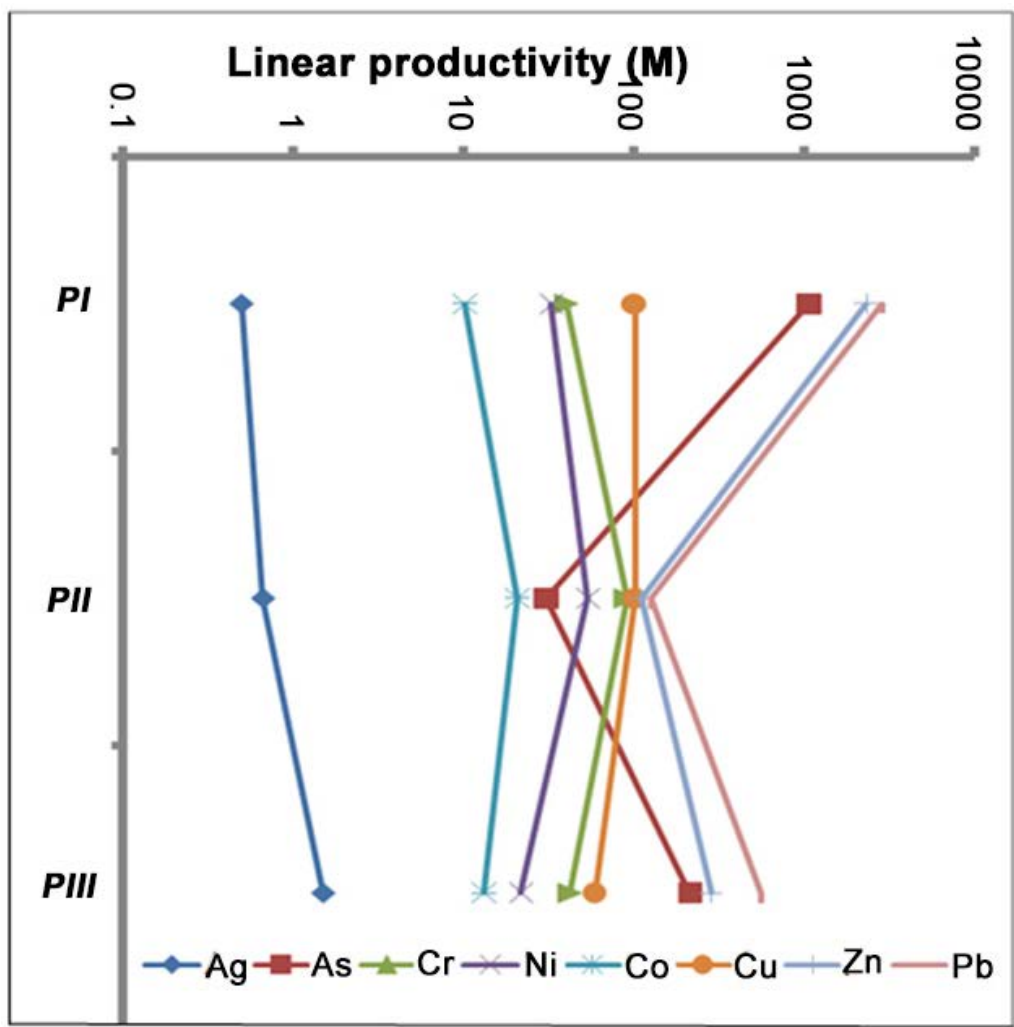

Figure 13. Linear Productivity (M) values plotted along the extension of the mineralization.

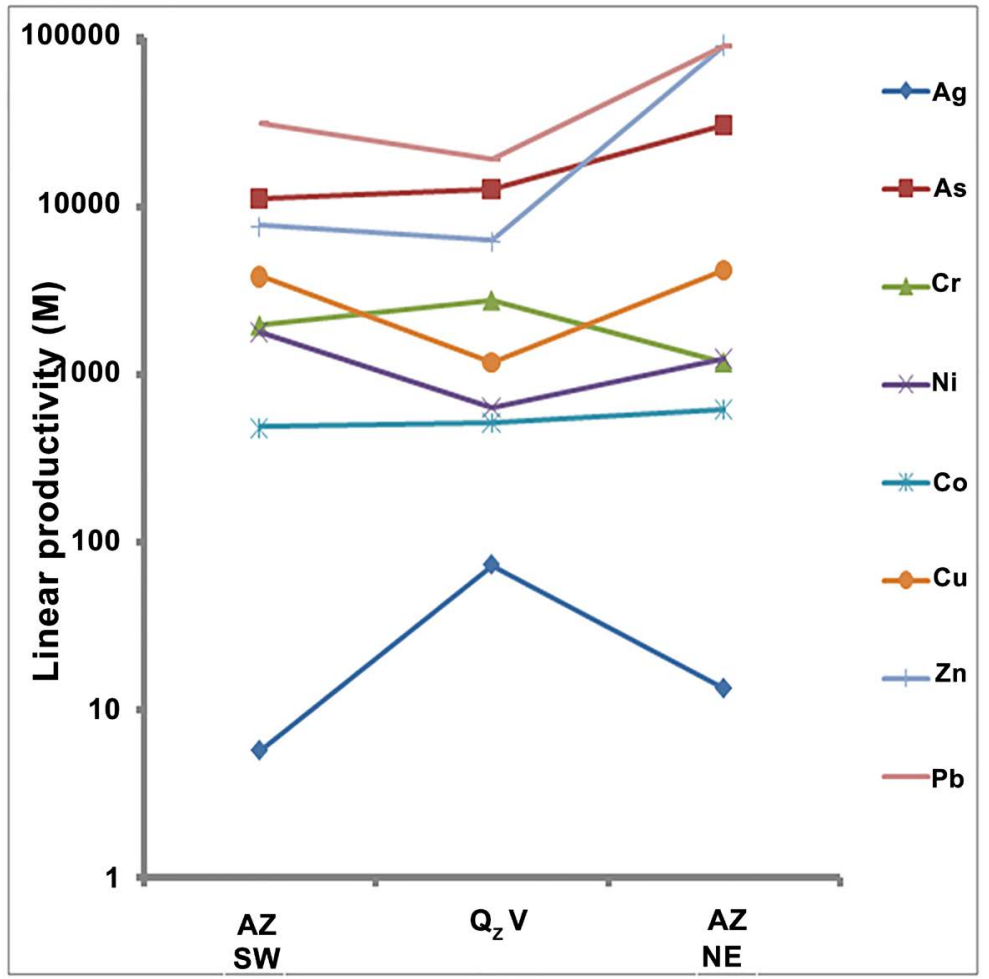

Figure 14. Total linear Productivity $(\mathrm{M})$ values perpendicular to the extension of alteration zones and quartz vein (SW-NE), El-Daghbag-I gold mine. 


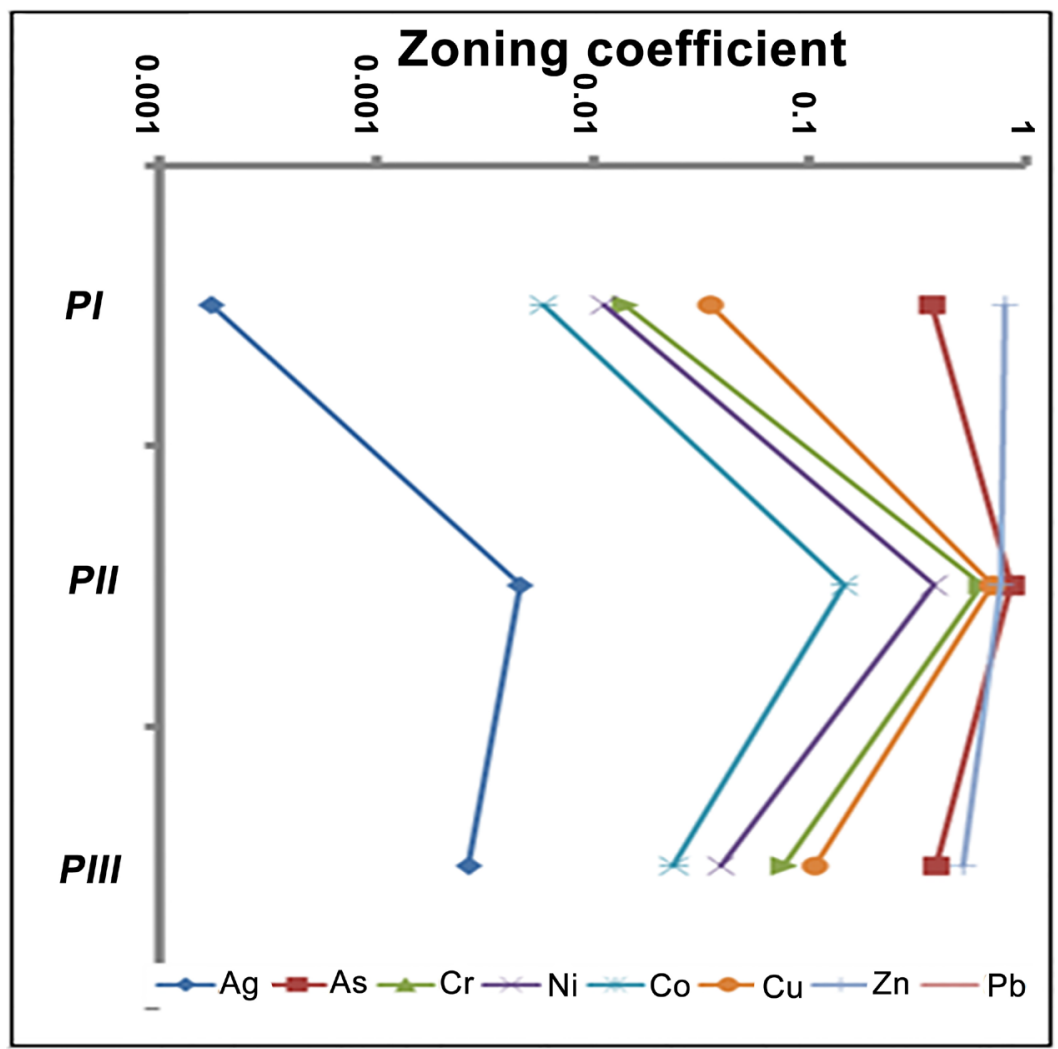

Figure 15. Zoning coefficient $(v)$ values plotted along the extension of the mineralization.

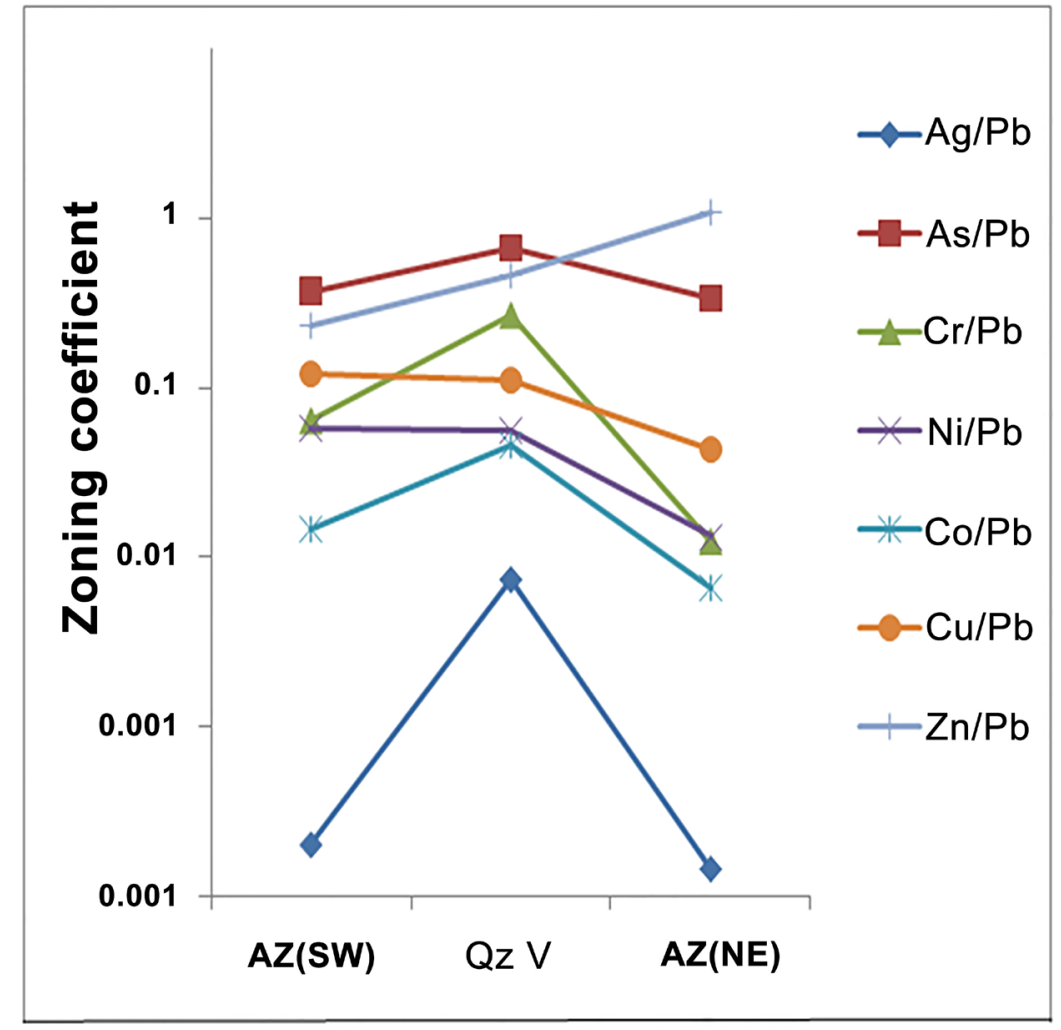

Figure 16. Zoning coefficient values plotted vs. lateral distance from (SW to NE). 
gold, pyrite, chalcopyrite, sphalerite and galena. Bornite, covellite and goethite are the secondary ore minerals. The paragenetic sequence of ore minerals forming El-Daghbag-I gold mineralization (Figure 11) shows that:

1) Magnetite and ilmenite existed as mineral constituents of the granodiorite associated with the magmatic stage.

2) Fine-grained pyrite and chalcopyrite were deposited from $\mathrm{Cu}$-Fe bearing solutions during the early reducing hydrothermal stage at temperature $\approx 300^{\circ} \mathrm{C}$. Gold was deposited early during this stage as native gold and incorporated in the fine-grained sulphide minerals.

3) During the lower temperature conditions, gross addition of sulfur led to formation of new sulphide generation chiefly sphalerite and galena.

4) Relatively lower temperature hydrothermal solutions $\left(<200^{\circ} \mathrm{C}\right)$ resulted in replacement processes that formed covellite and bornite after chalcopyrite.

5) Under supergene conditions, Fe-silica rich solutions deposited their oxides within these fractures and fissures cutting across the quartz veins, alteration zones and host rocks. Also, all Fe-bearing minerals were transformed into iron hydr-oxides, mainly goethite and hematite under the oxidizing surface condition.

From studying distribution patterns of El-Daghbag-I gold mineralization, it is clear that the ore elements $\mathrm{Ag}, \mathrm{As}, \mathrm{Co}, \mathrm{Cu}, \mathrm{Cr}, \mathrm{Ni}, \mathrm{Pb}$ and $\mathrm{Zn}$ form the geochemical association of the mineralization. These elements most probably occur as sulfide-minerals which are supported by ore-microscopic study. The recorded significant correlation coefficient values between these ore elements favor existence of these elements either in proper ore minerals recorded by microscopic studies and/or incorporated within the crystal lattice of these sulfide minerals.

The plotted diagrams of the linear productivity ( $\mathrm{M} \%)$ and zoning coefficient $(v)$ versus the extension and perpendicular to the mineralized zone (Figures 13-16) show that the Ag linear productivity values (M) increase southward at profile III and vice versa for $\mathrm{Pb}, \mathrm{Zn}$ and As while those for $\mathrm{Co}, \mathrm{Ni}, \mathrm{Cr}$ and $\mathrm{Cu}$ are high in the central part than the northern and southern parts of the lode and associated alteration zones. Regard to position of the ore metals in the general zoning sequence of [33] the gold potential of the central and southeastern parts, due to its probable accumulation at deeper levels of the mineralization, are expected to be promising. Drilling is recommended for studying the vertical zoning of these elements to reveal the site of gold accumulation.

\section{Conclusions}

The gold mineralization at El-Daghbag-I gold mine is represented by several NW-trending quartz veins cutting across highly sheared granodioritic rocks along NW-trending shear zone.

- The recorded ore mineral assemblage is native gold, magnetite, ilmenite, pyrite, chalcopyrite, sphalerite, galena, bornite, covellite and geoethite.

- The gold associated elements are ( $\mathrm{Cu}, \mathrm{As}, \mathrm{Zn}, \mathrm{Ni}, \mathrm{Co}, \mathrm{Ag}$ and $\mathrm{Pb})$. These elements occur as sulfide-minerals. 
- The most promising parts for gold exploitation along this vein are the central and southeastern parts.

- Drilling is recommended for studying the vertical zoning of these elements to reveal the site of gold accumulation.

\section{References}

[1] Hassaan, M.M. and El Mezayen, A.M. (1995) Genesis of Gold Mineralization in the Eastern Desert, Egypt. Al-Azhar Bulletin of Science, 5, 921-939.

[2] Botros, N.S. (2002) Metallogeny of Gold in Relation to the Evolution of the Nubian Shield in Egypt. Ore Geology Review, 19, 137-164.

[3] Botros, N.S. (2004) A New Classification of the Gold Deposits of Egypt. Ore Geology Review, 25, 1-37.

[4] Ramadan, T.M. and Kontny, A. (2004) Mineralogical and Structural Characterization of Alteration Zones Detected by Orbital Remote Sensing at Shalatein District area, SE Desert, Egypt. Journal of African Earth Sciences, 40, 89-99.

[5] Ramadan,T.M., Sadek, M.F., Abu El Leil, I. and Salem, S.M. (2005) Um El Touyur El Fuqani Gold Mineralization, South Eastern Desert, Egypt: Using Landsat ETM+ Imagery. Annals of the Geological Survey of Egypt, 28, 263-281.

[6] Khalil, K.I., Moghazi A.M. and El Makky, A.M. (2016) Nature and Geodynamic Setting of Late Neoproterozoic Vein-Type Gold Mineralization in the Eastern Desert of Egypt: Mineralogical and Geochemical Constraints. In: Bouabdellah, M. and Slack, J.F., Eds., Mineral Deposits of North Africa, Mineral Resource Reviews, Springer, International Publishing, Switzerland, 353-370.

[7] Hassaan, M.M., Soliman, M.M., Azzaz, S.A. and Attawiya, M.Y. (1990) Geological Studies on Gold Mineralization at Sukkari, Um Ud and Samut, Eastern Desert, Egypt. Annals of the Geological Survey of Egypt, 16, 89-95.

[8] Oweiss, Kh.A. (1995) Geochemical Exploration for Gold at Um Ud, Central Eastern Desert, Egypt. Annals of the Geological Survey of Egypt, 20, 327-332.

[9] Arslan, A.I. (1999) Vertical Geochemical Zonation of Gold in the Umm Rus Gold mine, Eastern Desert, Egypt. The 4th International Conference on Geochemistry, Alexandria University, Egypt, 15-16 September, 1999, 373-388.

[10] Arslan, A.L, Khalil, S.O., El-Sayed, M.M., Mohamed, F.H. and El Deeb, H.M. (2001) Contribution to the Geochemistry of Bedrocks and Wallrock Alterations, the El-Eradiya Gold Mine Area, Central Eastern Desert, Egypt. The 5th International Conference on Geochemistry, Alexandria University, Egypt, 12-13 September, 2001, 571-597.

[11] Ramadan, T.M. (2002) Exploration for Gold-Bearing Listwaenites at Um Khasila Area, Central Eastern Desert, Egypt. Egyptian Journal of Remote Sensing and Space Sciences, 5, 63-76.

[12] Zoheir, B., Akawy, A. and Hassan, I. (2008) Role of Fluid Mixing and Wallrock Sulfidation in Gold Mineralization at the Semna Mine Area, Central Eastern Desert of Egypt: Evidence from Hydrothermal Alteration, Fluid Inclusions and Stable Isotope Data. Ore Geology Reviews, 34, 580-596.

[13] Zoheir, B. and Akawy, A. (2010) Genesis of the Abu Marawat Gold Deposit, Central Eastern Desert of Egypt. Journal of African Earth Sciences, 57, 306-320.

[14] Zoheir, B. and Lehmann, B. (2011) Listvenite-Lode Association at the Barramiya Gold Mine, Eastern Desert, Egypt. Ore Geology Reviews, 39, 101-115.

[15] Amer, R., Kusky, T. and El Mezayen, A. (2012) Remote Sensing Detection of Gold 
Related Alteration Zones in Um Rus Area, Central Eastern Desert of Egypt. Advances in Space Research, 49, 121-134.

[16] Salem, S.M., Soliman, N.M., Ramadan, T.M. and Greiling T.M. (2013) Exploration of New Gold Occurrences in the Alteration Zones at the Barramiya District, Central Eastern Desert of Egypt Using ASTER Data and Geological Studies. Arabian Journal of Geosciences, 7, 1717-1731. https://doi.org/10.1007/s12517-013-0874-9

[17] Zoheir, B. and Weihed, P. (2014) Greenstone-Hosted Lode-Gold Mineralization at Dungash Mine, Eastern Desert, Egypt. Journal of African Earth Sciences, 99, 165187.

[18] Helmy, H. and Zoheir, B. (2014) Metal and Fluid Sources in a Potential WorldClass Gold Deposit: El Sid Mine, Egypt. International Journal of Earth Sciences, 104, 645-661. https://doi.org/10.1007/s00531-014-1094-6

[19] Abdelnasser, A. and Kumral, M. (2016) Mineral Chemistry and Geochemical Behavior of Hydrothermal Alterations Associated with Mafic Intrusive-Related Au Deposits at the Atud Area, Central Eastern Desert, Egypt. Ore Geology Reviews, 77, $1-24$.

[20] Dourgham, I.A., Fawzy, Kh.M. and Frimmel, H.E. (2017) Ore Minerals and Geochemical Characterization of the Dungash Gold Deposit, South Eastern Desert. Egypt. Arabian Journal of Geosciences, 10, 145. https://doi.org/10.1007/s12517-017-2891-6

[21] Klemm, R. and Klemm, D. (2013) Gold and Gold Mining in Ancient Egypt and Nubia, Geoarchaeology of the Ancient Gold Mining Sites in the Egyptian and Sudanese Eastern Deserts. Springer-Verlag, Berlin, Heidelberg, 663 p.

[22] Amer, A.F. and Mansour, A.O. (1955) Geology of El-Daghbag-El Gindy District, Barramiya East \& Barramiya West Sheets. Geological Survey of Egypt, Report, 67 p.

[23] Kotchin, G. and Bassyuni, F. (1968) The Mineral Resources of the UAR. Part1: Metallic Minerals. Internal Report EGSMA-Technoexport, Contract 1247, Cairo.

[24] El Baghdady, M.M. (1999) Geology and Geochemistry of El-Daghbag-El Hidlawi Area Central Eastern Desert, Egypt. PhD Thesis, Cairo University, Cairo, 195 p.

[25] Abdel Kader, Z., Hassanien, S.M., Ahmed, A.A. and El Baghdady, M.M. (2000) Geology and Geochemistry of El-Daghbag-El Miyah ophiolite, Central Eastern Desert, Egypt. Proceedings of the 5 th International Conference on the Geology of the Arab World, Cairo University, 57-74.

[26] Samaan, J.M. and Basta, M.S. (2004) Geology, Petrology and Radioactivity for the Granitoid Rocks of Wadi El-Daghbag Area, Central Eastern Desert, Egypt. 6th International Conference on Geochemistry, Alexandria University, Egypt, 15-16 September 2004, 465-481.

[27] Hassaan, M.M., Azzaz, S.A., Soliman, M.M. and El-Badawy, E. (1991) Use of Some Statistical and Geochemical Parameters in Solving Some Genetic Problems of Sukkari Gold Mineralization, Egypt. 48th I-S.I. Sess., Cairo, 9-17.

[28] Hassaan, M.M. (1999) A Review on Role of Geochemical Zonal Distribution of Chemical Elements in Delineation of Sites of Gold Localization in Some Mines, Egypt. Seventh Arab mineral resources, Cairo, October 1999, pp. 25-28, p. 26.

[29] Hassaan, M.M. (2011) Metallic Ore Deposits of the Nubian Shield in Egypt; Tectonic Environs, Geochemical Behavior, Promising Sites. LAP Lambert Academic Publishing, Gmbrt \& Co. KG and Licensors.

[30] Fawzy, Kh.M., Abdel Rahman, E.M. and Emam, A.A. (2012) Mineralogical and Geochemical Studies on Haimur and Hariari Gold Deposits, Wadi Allaqi District, south Eastern Desert, Egypt. Annals of the Geological Survey of Egypt, V. XXXI 
(2009-2011), 319-348.

[31] Hassaan, M.M., Fawzy, Kh.M. and Emam, A.A. (2015) Geochemical Zonal Distribution of Gold and Associating Elements at Site (s.II), Marahiq Gold Mineralization, Wadi Allaqi District, Southern Eastern Desert, Egypt. International Journal of Innovative Science, Engineering \& Technology, 2, 817-834.

[32] Turekian, K.K. and Wedepohl, K.H. (1961) Distribution of the Elements in Some Major Units of the Earth Crust. Geological Society of America Bulletin, 72, 175-192. https://doi.org/10.1130/0016-7606(1961)72[175:DOTEIS]2.0.CO;2

[33] Hassaan, M.M. (1977) Use of Geochemical Zoning in Solving Some Geologic Problems of Umm Gheig Pb-Zn Deposit. Third Arab Mineral Wealth Conference, Rabat, December, 179-192.

Submit or recommend next manuscript to SCIRP and we will provide best service for you:

Accepting pre-submission inquiries through Email, Facebook, LinkedIn, Twitter, etc. A wide selection of journals (inclusive of 9 subjects, more than 200 journals)

Providing 24-hour high-quality service

User-friendly online submission system

Fair and swift peer-review system

Efficient typesetting and proofreading procedure

Display of the result of downloads and visits, as well as the number of cited articles Maximum dissemination of your research work

Submit your manuscript at: http://papersubmission.scirp.org/

Or contact ojg@scirp.org 